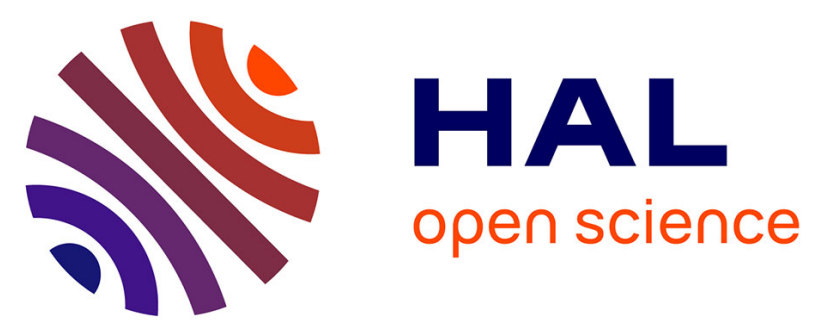

\title{
Coupling statistically downscaled GCM outputs with a basin-lake hydrological model in subtropical South America: evaluation of the influence of large-scale precipitation changes on regional hydroclimate variability \\ M. Troin, Mathieu Vrac, Myriam Khodri, C Vallet-Coulomb, E. Piovano, Florence Sylvestre
}

\section{- To cite this version:}

M. Troin, Mathieu Vrac, Myriam Khodri, C Vallet-Coulomb, E. Piovano, et al.. Coupling statistically downscaled GCM outputs with a basin-lake hydrological model in subtropical South America: evaluation of the influence of large-scale precipitation changes on regional hydroclimate variability. 2015. hal-00759259

\author{
HAL Id: hal-00759259 \\ https://hal.science/hal-00759259
}

Preprint submitted on 2 Dec 2015

HAL is a multi-disciplinary open access archive for the deposit and dissemination of scientific research documents, whether they are published or not. The documents may come from teaching and research institutions in France or abroad, or from public or private research centers.
L'archive ouverte pluridisciplinaire HAL, est destinée au dépôt et à la diffusion de documents scientifiques de niveau recherche, publiés ou non, émanant des établissements d'enseignement et de recherche français ou étrangers, des laboratoires publics ou privés. 
Hydrol. Earth Syst. Sci. Discuss., 7, 9523-9565, 2010 www.hydrol-earth-syst-sci-discuss.net/7/9523/2010/ doi:10.5194/hessd-7-9523-2010

(C) Author(s) 2010. CC Attribution 3.0 License.
Hydrology and Earth System Sciences Discussions

\section{Coupling statistically downscaled GCM}

outputs with a basin-lake hydrological model in subtropical South America: evaluation of the influence of large-scale precipitation changes on regional hydroclimate variability

M. Troin ${ }^{1}$, M. Vrac ${ }^{2}$, M. Khodri ${ }^{3}$, C. Vallet-Coulomb ${ }^{1}$, E. Piovano ${ }^{4}$, and F. Sylvestre ${ }^{1}$

${ }^{1}$ CEREGE, Aix-Marseille Université, CNRS, IRD, Europôle méditerranéen de l'Arbois BP 80 13545 Aix-en-Provence cedex 4, France

${ }^{2}$ Laboratoire des Sciences du Climat et de l'Environnement (LSCE-IPSL) CNRS-CEA-UVSQ, Centre d'étude de Saclay, Orme des Merisiers, Bat. 70191191 Gif-Sur-Yvette, France

HESSD

7, 9523-9565, 2010

Coupling statistically downscaled GCM outputs with a basin-lake model

M. Troin et al.

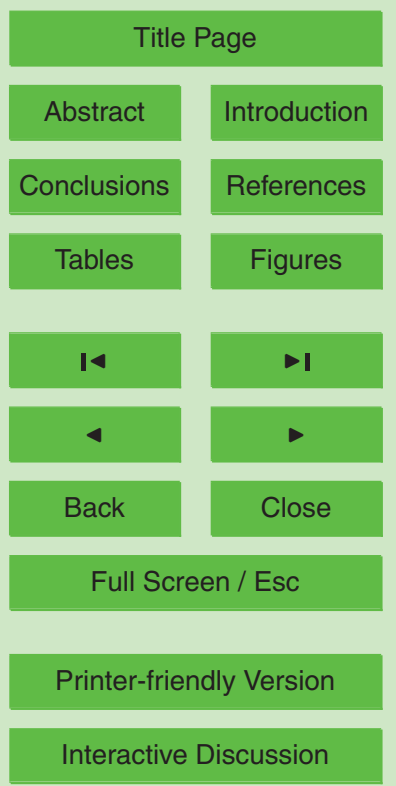


${ }^{3}$ LOCEAN, Paris 7 Université, IRD, CNRS, MNHN, UPMC/IPSL, Tour 45-55, 4. étage, 4 place Jussieu, 75252 Paris cedex 5, France

${ }^{4}$ CICTERRA-CIGeS, Universidad Nacional de Córdoba, Av. Velez Sarsfield 1611, X5016GCA

- Córdoba, Argentina

Received: 2 December 2010 - Accepted: 7 December 2010 - Published: 10 December 2010

Correspondence to: M. Troin (troin @ cerege.fr)

Published by Copernicus Publications on behalf of the European Geosciences Union.

\section{HESSD}

7, 9523-9565, 2010

Coupling statistically downscaled GCM outputs with a basin-lake model

M. Troin et al.

Title Page

Abstract Introduction

Conclusions References

Tables Figures

14

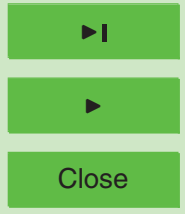

Back

Full Screen / Esc

Printer-friendly Version

Interactive Discussion 


\section{Abstract}

We explore the reliability of large-scale climate variables, namely precipitation and temperature, as inputs for a basin-lake hydrological model in central Argentina. We used data from two regions in NCEP/NCAR reanalyses and three regions from LMDZ model simulations forced with observed sea surface temperature (HadISST) for the last 50 years. Reanalyses data cover part of the geographical area of the Sali-Dulce Basin (region A) and a zone at lower latitudes (region B). The LMDZ selected regions represent the geographical area of the Sali-Dulce Basin (box A), and two areas outside of the basin at lower latitudes (boxes $B$ and $C$ ). A statistical downscaling method is used to connect the large-scale climate variables inferred from LMDZ and the reanalyses, with the hydrological Soil Water Assessment Tool (SWAT) model in order to simulate the Rio Sali-Dulce discharge during 1950-2005. The SWAT simulations are then used to force the water balance of Laguna Mar Chiquita, which experienced an abrupt level rise in the 1970's attributed to the increase in Rio Sali-Dulce discharge. Despite that the lowstand in the 1970's is not well reproduced in either simulation, the key hydrological cycles in the lake level are accurately captured. Even though satisfying results are obtained with the SWAT simulations using downscaled reanalyses, the lake level are more realistically simulated with the SWAT simulations using downscaled LMDZ data in boxes $B$ and $C$, showing a strong climate influence from the tropics on lake level fluctuations. Our results highlight the ability of downscaled climatic data to reproduce regional climate features. Laguna Mar Chiquita can therefore be considered as an integrator of large-scale climate changes since the forcing scenarios giving best results are those relying on global climate simulations forced with observed sea surface temperature. This climate-basin-lake model is a promising approach for understanding and simulating long-term lake level variations.
HESSD

7, 9523-9565, 2010

\section{Coupling statistically downscaled GCM outputs with a basin-lake model}

M. Troin et al.

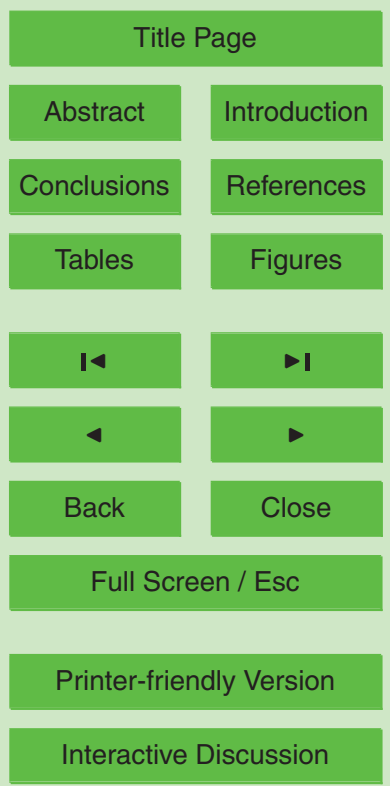




\section{Introduction}

Improving the understanding of climate change has become a major challenge in southeastern South America (SESA) region, where environmental impacts are expected to produce important and immediate costs on local economy and society. While 5 the first three quarters of the 20th century were affected by prolonged drought time period, this region has experienced an unprecedented humid phase since the early 1970's (Garcia and Vargas, 1998; Garcia and Mechoso, 2005; Pasquini et al., 2006). This still ongoing wet period results from an increase in precipitation and a higher frequency and severity of extreme hydrologic events in both the Paraná-Plata Basin and central 10 Argentina (Genta et al., 1998; Camilloni and Barros, 2003; Berbery and Barros, 2003; Planchon and Rosier, 2005).

Laguna Mar Chiquita $\left(30^{\circ} 54^{\prime} \mathrm{S}-62^{\circ} 51^{\prime} \mathrm{W}\right)$, the terminal saline lake of a $127000 \mathrm{~km}^{2}$ catchment area in central Argentina, west of the Paraná-Plata Basin, has clearly experienced the 20th century hydroclimatic changes through an abrupt water level rise in the early 1970's. Such abrupt and persistent lake level rise is without precedent over the last millennium according to paleolimnological reconstruction based on lacustrine archives (Piovano et al., 2002; Sylvestre et al., 2010). A recent study was conducted to assess and simulate the lake level response to regional climate and runoff variability (Troin et al., 2010). The results pointed out to the dominant contribution of the northern fluence. An integrated basin-lake hydrological approach combining the watershed Soil Water Assessment Tool (SWAT) model with the lake water balance was then developed (Troin et al., 2010). This latter has demonstrated the performance of this coupled hydrological model to simulate the lake level fluctuations during the 1970's hydroclimatic transition. In this paper, we want to go a step further. The major objective is to provide an efficient integrated large-scale climate-basin-lake model in order to understand and simulate its long-term past and future behaviours in relation with global climate. The large-scale outputs of general circulation models (GCMs) can be extremely useful for
HESSD

7, 9523-9565, 2010

\section{Coupling statistically downscaled GCM outputs with a basin-lake model}

M. Troin et al.

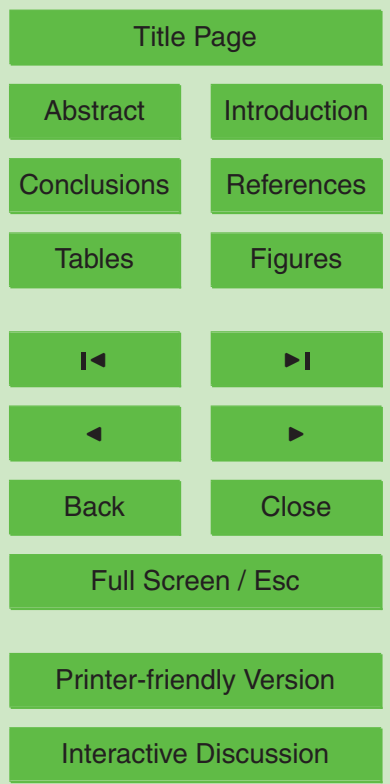


projecting and understanding future global climatic changes and their impacts on hydrological systems. Although results vary between studies, hydrological models driven directly by raw outputs of GCMs performed poorly and the predicted runoff is often oversimplified (Wilby et al., 1999; Xu, 1999). The spatial resolution of the present GCMs is 5 too coarse to resolve local-scale processes, precluding their direct use in hydrological models (Wilks and Wilby, 1999; Prudhomme et al., 2002). In particular, the reproduction of observed spatial patterns of precipitation (Salathé, 2003) and daily precipitation variability (Bürger and Chen, 2005) is not sufficient. Thus, considerable efforts have been made in the climate community in order to develop downscaling methods, to over10 come the gap between large- and local-scale climate data required for hydrological models (Wilby et al., 1999; Hay et al., 2002; Hay and Clark, 2003; Chiew et al., 2010). The most widely used are classified into dynamical and statistical approaches. The first approach refers to the regional climate models (RCMs). Resolving the physical equations of the atmospheric regional dynamics, RCMs are meteorologically and hydrologically consistent but also computationally expensive in the production of regional simulations (Tisseuil et al., 2010). Wood et al. (2004) have found that RCMs do not lead to large improvement in hydrological simulations relative to using GCMs outputs alone. In the statistical approach, statistical downscaling methods (SDMs) are used to generate local-scale climate variables from large-scale climate variables derived from GCMs outputs or reanalyses. In the usual SDMs, such as regression models (e.g., Wilby et al., 2002; Vrac et al., 2007a, Huth et al., 2008), weather typing schemes (e.g., Mamassis and Koutsoyiannis, 1996; Vrac et al., 2007b), and stochastic weather generators (e.g., Wilks and Wilby, 1999; Vrac and Naveau, 2007), the fundamental concept is to relate one or several large-scale climate variables (the predictors) from GCMs or reanalyses to local-scale climate variables (the predictands). While most of the SDMs usually consider direct relationships in order to provide local-scale climate values, the probabilistic downscaling methods (PDMs) model large-scale climate statistics in view of generating local-scale climate statistics (Michelangeli et al., 2009). Thanks to advances in availability of concerted experiments among the climate community, there is

\section{HESSD}

7, 9523-9565, 2010

\section{Coupling statistically downscaled GCM outputs with a basin-lake model}

M. Troin et al.

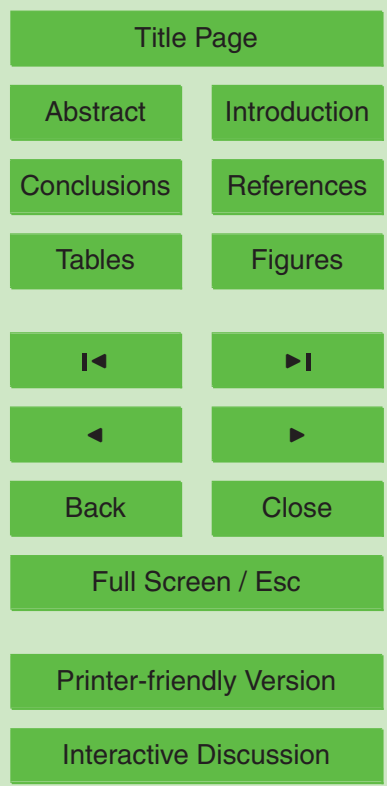


some interest in the use of PDMs such as computational efficiency and stronger relations to the local-scale climate, which seem to offer a more robust way for assessing climate impacts on hydrological systems (Fowler et al., 2007).

In this context, our study aims at assessing the applicability of the integrated basin5 lake hydrological model forced by statistically downscaled large-scale climate variables. To do so, we use a PDM approach for simulating the lake level variations of Laguna Mar Chiquita during the 1970's hydroclimatic transition. The large-scale times series are data fields derived from the National Center for Environmental Prediction (NCEP)/National Center for Atmospheric Research (NCAR) reanalyses and the CM4 coupled model of the Institut Pierre Simon Laplace developed at Laboratoire de Météorologie Dynamique (Marti et al., 2005; Dufresne et al., 2005).

Doing so, we will address the following questions: (1) Is it relevant to force a rainfallrunoff model by downscaled NCEP/NCAR reanalyses and LMDZ GCM outputs? Are the GCMs projections reliable at a local-scale?; (2) Did the large-scale simulated precipitations forced by observed sea surface temperature (HadSST1) for that period represent the climatic control of the lake level fluctuations? If so, can Laguna Mar Chiquita be considered as an integrator of global climate variability in the SESA?

After a brief description of the area of study (Sect. 2), the five large-scale times series derived from the reanalyses regions and LMDZ boxes are presented (Sect. 3). In Sect. 4, the methodology used to generate rainfall-runoff simulations is described as well as lake-level simulations. In Sect. 5, the downscaling method performance is analysed during the calibration and validation periods, and the simulations are evaluated. Then, in Sect. 6, we discuss the ability of our approach to reproduce regional climate

\section{HESSD}

7, 9523-9565, 2010

\section{Coupling statistically downscaled GCM outputs with a basin-lake model}

M. Troin et al.

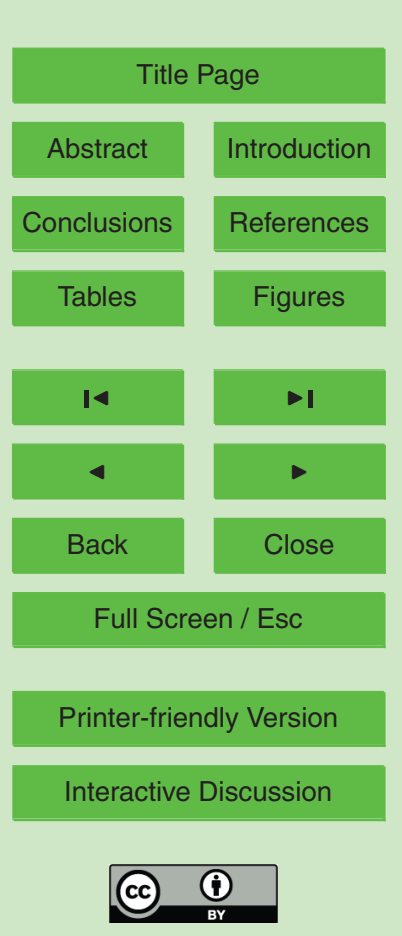




\section{General description of the study area}

\subsection{The lake watershed}

HESSD

Laguna Mar Chiquita $\left(30^{\circ} 54^{\prime} \mathrm{S}-62^{\circ} 51^{\prime} \mathrm{W}\right)$ is a hydrologically closed terminal lake occupying a tectonic depression that formed during the middle Pleistocene (Krohling and 5 Iriondo, 1999). The lake catchment is estimated to $127000 \mathrm{~km}^{2}$ from $26^{\circ} \mathrm{S}$ to $32^{\circ} \mathrm{S}$ and from $62^{\circ} \mathrm{W}$ to $66^{\circ} \mathrm{W}$ (Fig. 1), with a relatively low relief except for its mountainous borders on the northwest and southwest, called Sierras de Aconquija and Pampeanas ranges, respectively. The lake catchment is part of the Chaco-Pampean Plain, a larger lowland area where grasslands and shrublands have been modified for agricultural activities during the last century (Gavier and Bucher, 2004).

\subsection{Hydrology of Laguna Mar Chiquita}

Laguna Mar Chiquita is fed by three rivers (Fig. 1) and likely receives substantial groundwater inputs. The main surface water inflow is from the Rio Sali-Dulce Basin which controls $92 \%$ of lake level variations (Troin et al., 2010). The Rio Sali-Dulce 15 Basin, covering roughly $23810 \mathrm{~km}^{2}$ from $26^{\circ} \mathrm{S}$ to $28^{\circ} \mathrm{S}$ and $64^{\circ} \mathrm{W}$ to $66^{\circ} \mathrm{W}$, drains the northern part of the lake basin. It is the collector of many rivers that come from the Sierra de Aconquija until joining the Rio Hondo reservoir, created in 1967 to control and regulate the water distribution and also to produce hydroelectric power (Fig. 1). The hydrographic network of the Sali-Dulce Basin provides ressources necessary to the regional socio-economic development. Other minor inflows to the lake, draining the southwestern part of the lake basin and coming from the Sierras Pampeanas area, are the Rios Xanaes and Suquía (Troin et al., 2010). The lake system has no surface outlet and the only significant water loss is evaporation, which is favored by the pan-like shape of the lake.

\section{Coupling statistically downscaled GCM outputs with a basin-lake model \\ M. Troin et al.}

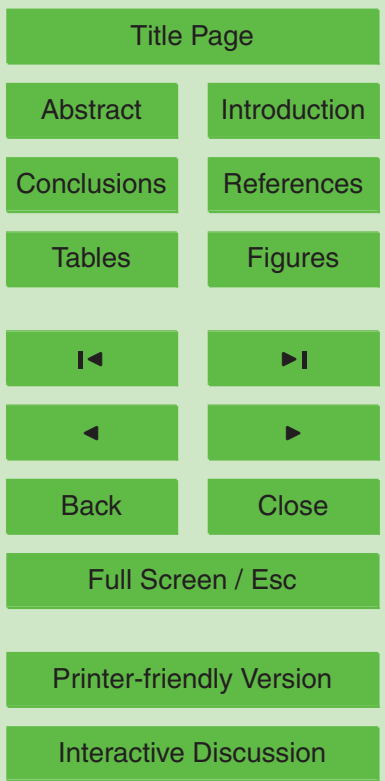




\subsection{Regional climate}

Characterized by a wet season (with high precipitation and temperature) from December to March and a dry season between June and August, the studied area is subjected to a latitude climate gradient. In the south, around Laguna Mar Chiquita, the

5 climate is warm-temperate (mean annual temperature of $18^{\circ} \mathrm{C}$ ) with mean annual precipitation of $806 \mathrm{~mm}$. Northward, the Sali-Dulce Basin is rather characterized by a subtropical climate (mean annual temperature of $20^{\circ} \mathrm{C}$ ) with mean annual precipitation of $1300 \mathrm{~mm}$. In the northern part of the Sali-Dulce Basin, orographic precipitations exceeding $1500 \mathrm{~mm}$ per year are observed.

10 The major atmospheric features driving seasonal climatic variability in the SESA is the South American Monsoon System (SAMS). In the austral summer, the SAMS extends southward from the tropical continental region connecting the tropical Atlantic Inter Tropical Convergence Zone (ITCZ) with the South Atlantic Convergence Zone (SACZ) through a large-scale atmospheric circulation containing a low-level jet (Zhou 15 and Lau, 1998). The South American low-level jet originating in the northern part of South America at the foot of the Andes is driven by the Chaco Low to provide moisture for the SESA, bringing vapor from the tropics to the subtropical latitudes (Labraga et al., 2000; Barros et al., 2002). In contrast, the SACZ displays a weak convective activity during the austral winter and rainfall regime deceases excepted at the East in SESA where the South East trade wind circulation brings moisture associated with local rainfall (Barros et al., 2002).

\section{Data}

\subsection{Local-scale meteorological and hydrological data}

Meteorological data in the lake basin for the 1950-2005 time period were obtained 25 from the Dirección Provincial de Agua y Saneamiento (DIPAS) in Argentina's Córdoba

HESSD

7, 9523-9565, 2010

\section{Coupling statistically downscaled GCM outputs with a basin-lake model}

M. Troin et al.

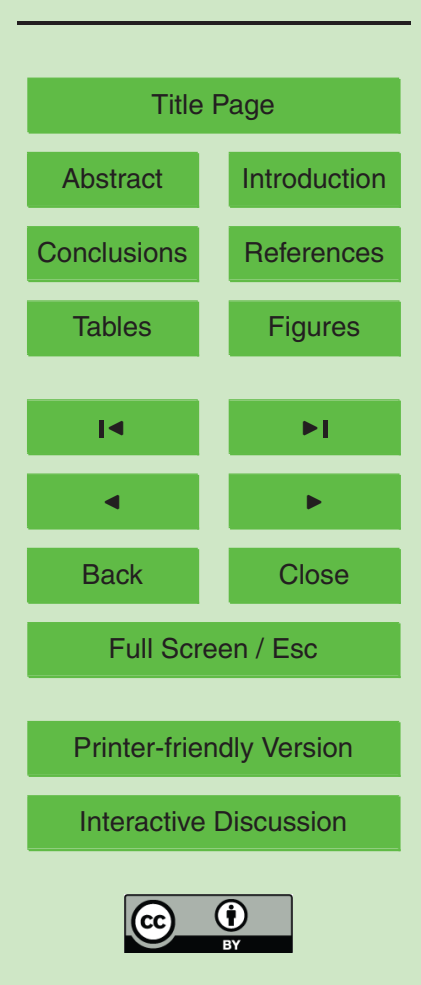


Province, the Instituto Nacional de Tecnologia Agropecuaria (INTA), the National Climatic Data Center (NCDC), and CLARIS LPB project database (http://www.claris-eu. $\mathrm{org} /$ ). It consists of daily minimum and maximum temperatures and precipitation for two stations during the 1950-2005 time period and four stations for 1973-2005 in the 5 Sali-Dulce Basin (Fig. 1 and Table 1).

Monthly river discharge was obtained from Argentina's Subsecretaría de Recursos Hídricos and the Laboratorio de Hidráulica at the Universidad Nacional de Córdoba (Table 2). The Rio Sali-Dulce is gauged after the reservoir at the Hondo station (Fig. 1), and a time series was obtained by combining two neighbouring gauging stations, 10 which were well correlated during the 1967-1982 common time period $\left(r^{2}=0.99\right)$. The Hondo gauging station covers the drainage area to the reservoir, e.g. $98 \%$ of the total Sali-Dulce Basin area (Fig. 1 and Table 2).

\subsection{Large-scale meteorological data}

\subsubsection{Reanalysis data}

15 NCEP/NCAR reanalysis data are atmospheric model outputs derived from the assimilation of surface observation stations, upper-air stations and satellite-observing platforms with long records starting in 1948 and continuing to present day. These data are typically viewed as observed large-scale data on a regular grid with a spatial resolution of 2.5 by 2.5 degrees in longitude and latitude directions. In this work, mean daily 1950-2005 time period were used, referred as region $\mathrm{A}$ (from $27^{\circ} \mathrm{S}$ to $28^{\circ} \mathrm{S}$ and $65^{\circ} \mathrm{W}$ to $66^{\circ} \mathrm{W}$ ) and region $\mathrm{B}$ (from $20^{\circ} \mathrm{S}$ to $25^{\circ} \mathrm{S}$ and $55^{\circ} \mathrm{W}$ to $65^{\circ} \mathrm{W}$ ), covering, respectively, part of the geographical area of the Sali-Dulce Basin and a zone at lower latitudes.

\section{HESSD}

7, 9523-9565, 2010

\section{Coupling statistically downscaled GCM outputs with a basin-lake model \\ M. Troin et al.}

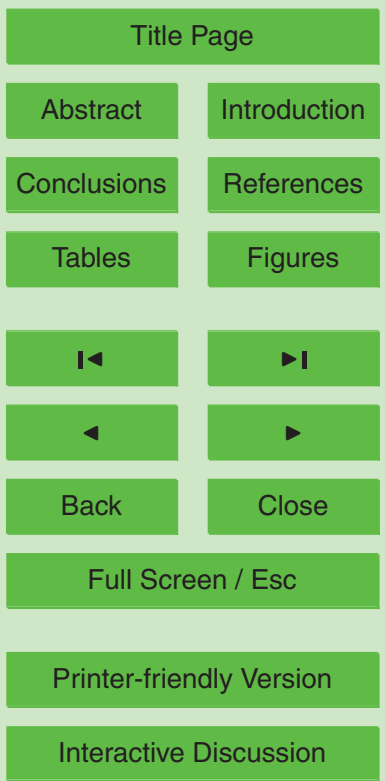




\subsubsection{General circulation model simulations}

The GCM used is the LMDZ version 4, the atmospheric component of the IPSL-CM4 coupled model of the Institut Pierre Simon Laplace (Marti et al., 2005), developed at Laboratoire de Météorologie Dynamique, and used to produce climate change simu5 lations for the 2007 IPCC report (Dufresne et al., 2005). The model is formulated in the finite-difference grid with a horizontal resolution of 3.75 by 2.5 degrees in longitude and latitude directions and 19 hydrid vertical layers (Hourdin et al., 2006). Using this model, we performed an ensemble of ten simulations forced by the observed sea surface temperature from 1951 to 2005, using the monthly HadSST1 global dataset

10 (Rayner et al., 2003). Each simulation member only differs from the sea ice and sea surface temperature used as initial conditions.

Daily minimum and maximum temperatures and precipitation averaged over the 10 members ensemble were then extracted for three regions from the model outputs, referred as box $\mathrm{A}$ (from $25^{\circ} \mathrm{S}$ to $35^{\circ} \mathrm{S}$ and $55^{\circ} \mathrm{W}$ to $67^{\circ} \mathrm{W}$ ), box $\mathrm{B}$ (from $15^{\circ} \mathrm{S}$ to $25^{\circ} \mathrm{S}$ 15 and $55^{\circ} \mathrm{W}$ to $65^{\circ} \mathrm{W}$ ), and box $\mathrm{C}$ (from $20^{\circ} \mathrm{S}$ to $25^{\circ} \mathrm{S}$ and $55^{\circ} \mathrm{W}$ to $65^{\circ} \mathrm{W}$ ). Box A covers the geographical area of lake basin, while the two others are located slightly north to the Sali-Dulce Basin, in order to put more emphasis on the possible tropical influence over the basin-lake hydrological evolution.

\section{Methodology}

20 The compiled data sets were used to develop five climate scenarios to investigate the potential reliability of downscaled data for generating discharge scenarios in the Rio Sali-Dulce Basin for the 1950-2005 time period. The description of the methodologies involved will follow the routes shown in the Fig. 2. Daily precipitation and temperature time series produced from probabilistically downscaled NCEP/NCAR reanalyses and LMDZ outputs were distributed spatially over the Sali-Dulce Basin in order to fit with the location of observed meteorological stations. These spatially distributed meteorological
HESSD

7, 9523-9565, 2010

\section{Coupling statistically downscaled GCM outputs with a basin-lake model}

M. Troin et al.

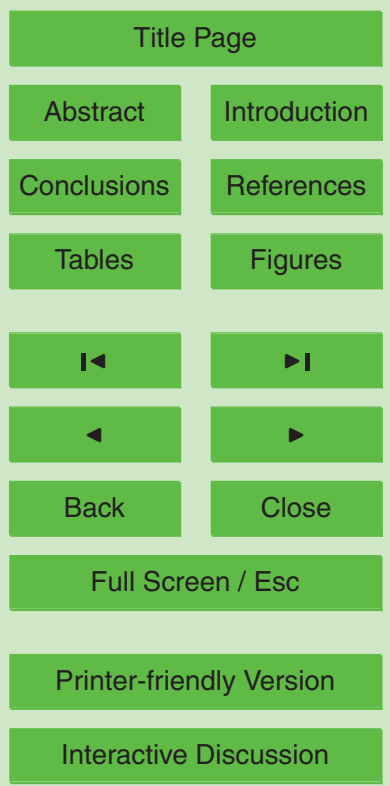


data were then used as input to the watershed hydrological SWAT model (Arnold et al., 1998; Neitsch et al., 2002) in order to simulate the main surface runoff that feed the lake for the 1950-2005 time period. At last, the level fluctuations of Laguna Mar Chiquita were simulated during the studied period by a lake water balance model (Troin 5 et al., 2010) forced by the outputs of SWAT. The following sections provide details of the methodology involved at each stage of the analysis.

\subsection{Probabilistic downscaling method}

Probabilistic downscaling methods (PDMs) involve modelling relationships between statistical characteristics of the predictors and those of the predictands. Predictor variables provide information concerning the daily large-scale state of the atmosphere, while predictands represent the local-scale variables to be modelled such as temperature and precipitation that are observed at meteorological stations. In this work, the predictor variables included daily precipitation and maximum and minimum temperatures. The statistical relationships between predictors and predictands were modeled al., 2009). The cumulative distribution function $F$ (CDF) of a random variable $X$ corresponds to the probability that a random realization of $X$ is equal to or lower than a given value $x$ : $F(x)=$ Proba $(X \leq x)$. The CDF-t method can be seen as an extension of the quantiles-matching method (Déqué, 2007) that uses non-parametric correspondences between predictors and predictands quantiles. The CDF-t approach is based on the assumption that a mathematical transformation $t$ allows to translate the CDF of the predictor (e.g. temperature and precipitation from reanalyses or LMDZ) into the CDF representing the predictand (e.g. temperature and precipitation at a meteorological station). CDF-t has the advantage to take into account the change in the large-scale 25 CDF from the observed period to the future one, that is required in a changing climate context (Michelangeli et al., 2009).

For the precipitation downscaling procedure, we first determined the daily precipitation occurrences before applying CDF-t to the strictly positive rainfall intensities. The
HESSD

7, 9523-9565, 2010

\section{Coupling statistically downscaled GCM outputs with a basin-lake model}

M. Troin et al.

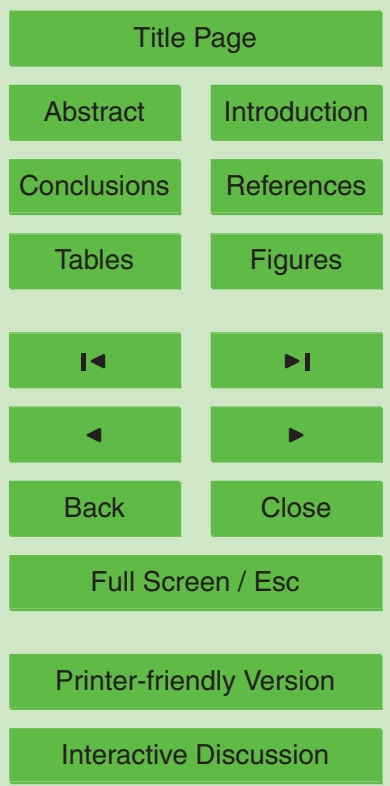

Interactive Discussion 
binomial distribution of the large-scale daily rainfall occurrences is often biased (in reanalyses or GCM outputs) in comparison to local observations. Hence, a threshold was defined to work on corrected large-scale occurrences distributions similar to the observed ones. In the following, we will consider that a daily local observation of rain corresponds to a wet day only if the observed intensity is $1 \mathrm{~mm}$ or higher. Otherwise, it is considered as a dry day. Then, for each given station $S$, a large-scale threshold $t_{S}$ is determined such that we have as many large-scale dry days - i.e., with large-scale rain intensities lower than $t_{\mathrm{S}}$ - as the number of observed dry days at station $S$. In other words, if $F_{\mathrm{S}}$ is the CDF of the rain intensity (including values lower than $1 \mathrm{~mm} \mathrm{day}^{-1}$ ) at 10 station $S$, and $F_{\mathrm{L}}$ the equivalent for the large scale data, then $t_{\mathrm{S}}$ is determined such that $F_{\mathrm{L}}\left(t_{\mathrm{S}}\right)=F_{\mathrm{S}}(1)$. Hence, based on this threshold, a large-scale sequence of rain occurrences can be obtained. Then, the large-scale values of the days where occurrences were determined (i.e., with rainfall $\geq t_{\mathrm{S}} \mathrm{mm}$ ) are downscaled using CDF-t.

Because the temperatures are continuous without real bounds in this study, the daily 15 distributions of the large-scale minimum and maximum temperatures derived from reanalyses and LMDZ were directly downscaled using CDF-t.

The precipitation and temperature downscaling procedures were applied in considering either all season grouped together or a seasons differentiation. Those two approaches are referred in the following as CDF-t-year and CDF-t-season, respectively. 20 In the latter, the seasons were determined based on the observed seasonality, i.e., wet (November to April) and dry (May to October) seasons.

\subsection{SWAT model description}

The hydrological Soil and Water Assessment Tool (SWAT) model (Arnold et al., 1998; Neitsch et al., 2002) was used in this study. SWAT is a continuous-time, spatially semidistributed hydrological watershed-scale model that operates on a daily time step. The model is physically based and is computationally efficient for large watersheds (Arnold and Allen, 1996). Spatial variability of land use, soil, and management practices are accounted for by dividing the watershed into sub-basins based on topography and the 9534
HESSD

7, 9523-9565, 2010

\section{Coupling statistically downscaled GCM outputs with a basin-lake model}

M. Troin et al.

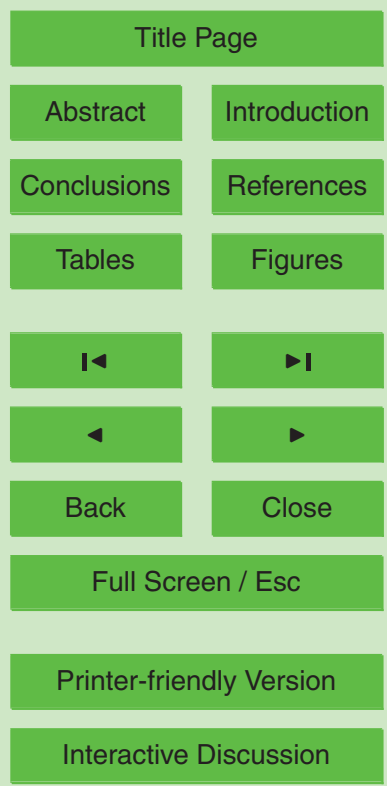

Interactive Discussion 
river network. Each sub-basin is divided in multiple Hydrologic Response Units (HRUs) that represent a unique combination of land cover, soil, and slope. The minimum climatic variables required for SWAT are precipitation, maximum and minimum temperatures. For a given time step, the contribution to discharge at each sub-basin outlet 5 is controlled by the HRU water balance calculation. The second phase is the routing phase which determines the movement of water through the river network towards the basin outlet (Neitsch et al., 2002). The HRU water balance is expressed as follows:

$W_{t}=W_{\mathrm{o}}+\sum_{i=1}^{t}\left(P_{i}-Q_{\text {isurf }}-\mathrm{ET}_{i}-W_{\text {iseep }}-Q_{\text {igw }}\right)$

where $W_{t}$ is the soil moisture content at the time $t$ (in $\mathrm{mm}$ of water); $W_{\mathrm{o}}$ is the initial soil moisture content ( $\mathrm{mm}$ of water); $P_{i}$ is the amount of precipitation on day $i(\mathrm{~mm}$ of water); $Q_{\text {isurf }}$ is the amount of surface runoff on day $i$ ( $\mathrm{mm}$ of water); $\mathrm{ET}_{i}$ is the amount of evapotranspiration on day $i\left(\mathrm{~mm}\right.$ of water); $w_{\text {iseep }}$ is the amount of percolated water through the soil profile ( $\mathrm{mm}$ of water); and $Q_{\text {igw }}$ is the amount of groundwater flow on day $i$ ( $\mathrm{mm}$ of water).

15 Surface runoff was estimated using the Soil Conservation Service (SCS) curve number procedure (SCS, 1972) and the potential evapotranspiration (PET) was determined by the Hargreaves method (Hargreaves and Samini, 1985). More details can be found in the SWAT User's Manual (Neitsch et al., 2002).

A detailed analysis of SWAT application to the Sali-Dulce Basin is provided in Troin et al. (2010). The SWAT peformance for simulating the surface runoff is evaluated at the monthly level based on available data, using the Nash-Sutcliffe effiency (NSE), that is a normalized statistic determining the relative magnitude of the residual variance compared to the observed data variance (Nash and Sutcliffe, 1970) from month $i$ to $n$,
HESSD

7, 9523-9565, 2010

\section{Coupling statistically downscaled GCM outputs with a basin-lake model}

M. Troin et al.

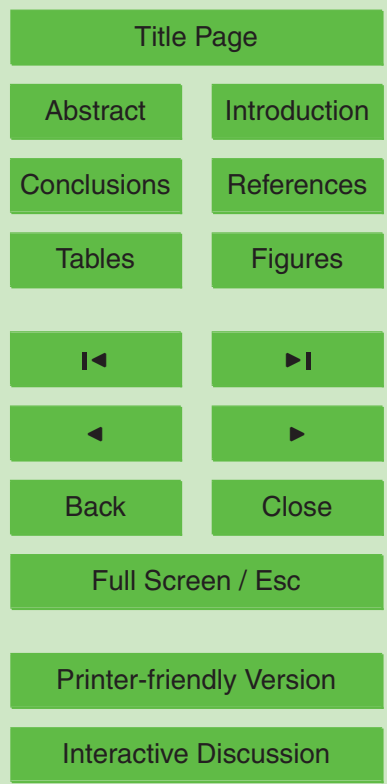


through:

NSE $=\frac{\sum_{i=1}^{n}\left(Q_{0}-\bar{Q}_{0}\right)^{2}-\sum_{i=1}^{n}\left(Q_{\mathrm{s}}-Q_{0}\right)^{2}}{\sum_{i=1}^{n}\left(Q_{0}-\bar{Q}_{0}\right)^{2}}$

HESSD

7, 9523-9565, 2010

Coupling statistically downscaled GCM

outputs with a basin-lake model

M. Troin et al.

A modeling study of lake level fluctuations in Laguna Mar Chiquita was recently performed (Troin et al., 2010). This study presented a water balance model able to simulate the lake level variations in response to local climate and observed monthly river discharge in its upper catchment (see location of gauging stations in Fig. 1). A detailed analysis of the lake model calibration and implementation is provided in Troin et al. (2010). The dynamic lake water balance of Laguna Mar Chiquita is simulated as follows:

$\frac{\delta V}{\delta T}=A(V)(P-E)+Q_{\text {in }}-\gamma$ with $Q_{\text {in }}=Q_{\mathrm{R} 1}+Q_{\mathrm{R} 2}+Q_{\mathrm{R} 3}$

where, for the monthly time step $\Delta t, \Delta V$ is the lake volume variation $\left(\mathrm{m}^{3}\right) ; A$ is the 15 lake area $\left(\mathrm{m}^{2}\right)$, as a function of the lake volume $V ; P$ is the on-lake precipitation $(\mathrm{m})$ estimated from the six rainfall stations surrounding the lake (Fig. 1); $E$ is the evaporation from the lake's surface $(\mathrm{m})$ calculated using the Complementary Relationship Lake Evaporation (CRLE) Model (Morton, 1983; DosReis and Dias, 1998); $Q_{\text {in }}$ is the water inflow from the catchment $\left(\mathrm{m}^{3}\right) ; Q_{\mathrm{R} 1}$ and $Q_{\mathrm{R} 2}$ the two southern river discharges; and ${ }_{20} Q_{\mathrm{R} 3}$ the Rio Sali-Dulce discharge, representing $90 \%$ of $Q_{\text {in }}$ (Fig. 1). The corresponding lake level was estimated as a function of the lake volume, $h=f(V)$, following the morphometric relationship established using the lake bathymetry (Hillman, 2003).

9536

\section{Title Page}

\section{Abstract}

Introduction

Conclusions

Tables

References

Figures

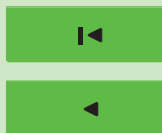

4

Back

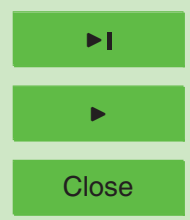

Full Screen / Esc

Printer-friendly Version

Interactive Discussion 


\section{Results}

\subsection{Evaluation of the downscaling method}

When calibrated during the 1973-1989 time period using the six observed data sets for both NCEP/NCAR reanalyses regions, CDF-t-year and CDF-t-season generally ex5 plained between 37 and $75 \%$ and between 48 and $74 \%$, respectively, of the percentage of explained variance $(\mathrm{E} \%)$ in daily maximum and minimum temperatures (Table 3 ). Slightly lower values were obtained from the three LMDZ boxes with a E\% statistic between 37 and $61 \%$ and between 40 and 59\%, respectively, for CDF-t-year and CDF-t-season (Table 4). Minimum temperatures were downscaled with more efficiency than maximum temperatures for both CDF-t-year and CDF-t-season and whatever the downscaled large-scale data (i.e. NCEP/NCAR reanalyses regions or LMDZ boxes) (Tables 3 and 4). Minimum and maximum temperatures were better reproduced during austral spring (SON) and automn (MAM) than austral winter (JJA) and summer (DJF).

From the Tables 3 and 4, it was evident that, on average, the PDM overestimated the yearly and seasonal occurrences of dry day while wet day occurences were underestimated, whatever the downscaled large-scale data (i.e. NCEP/NCAR reanalyses regions and LMDZ boxes) and the downscaling method (i.e. CDF-t-year and CDF-tseason). The proportions of dry and wet days occurrences were better reproduced during austral summer (DJF) except for region B (CDF-t-year and CDF-t-season), and boxes $B$ (CDF-t-year) and C (CDF-t-season), where the precipitation occurrences were better represented, during austral spring (SON) and winter (JJA), respectively for the two boxes. Additionaly, simulated precipitation consistently reproduced the probability of observed wet and dry spells, even for small values of probabilities, corresponding to long periods (Figs. 3 and 4). Again, a tendency to underestimate the wet spell

PDM validation was peformed during the 1990-2005 time period using the lengthy series of the six meteorological stations. Before the year 1972, the performance of the yearly and seasonal CDF-t's was evaluated based on two available meteorological

HESSD

7, 9523-9565, 2010

\section{Coupling statistically downscaled GCM outputs with a basin-lake model}

M. Troin et al.

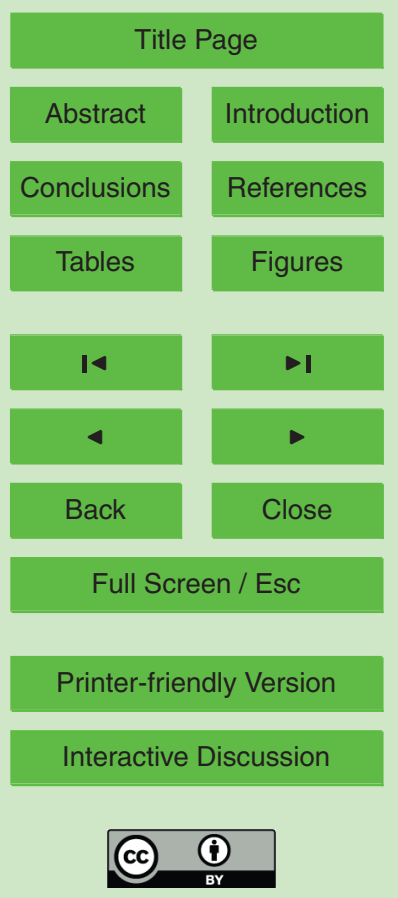


stations (Table 1). Even though the percentage of wet days remained underestimated for the NCEP/NCAR reanalysis regions and the LMDZ boxes during both the PDM validation periods, the annual precipitation totals were quite similar to the observed one, especially for the boxes $\mathrm{B}$ and $\mathrm{C}$ (Tables 5 and 6 ). The downscaled maximum and 5 minimum temperatures were under- and over-estimated, respectively, from both the reanalysis regions and LMDZ boxes (Tables 5 and 6 ). It is noteworthy that a season differentiation did not allow a clear improvement of the downscaled local climate.

\subsection{Comparison of rainfall-runoff simulations}

In this section, we compared the SWAT performance to simulate the Rio Sali-Dulce 10 discharge forced by the downscaled daily precipitation and temperature derived from reanalysis regions and LMDZ boxes over the PDM calibration (1973-1989) and validation periods (1950-1972; 1990-2005). Additional figures presenting the scatter plots of measured versus simulated monthly runoff over the PDM calibration and validation periods can be found in Appendixes $A$ to $F$.

15 Accordingly, Table 7 showed the corresponding Nash-Sutcliffe coefficient of efficiency (NSE) statistics for both downscaled reanalyses regions and LMDZ boxes used as input data to SWAT over the PDM calibration and validation periods.

For SWAT simulations obtained using the downscaled reanalysis regions during the PDM 1973-1989 calibration time period, the best results were found for region A with the CDF-t-season method (Table 7). However, more satisfying results were observed using the downscaled LMDZ boxes $B$ and $C$ with a better SWAT skill using the CDFt-year (Table 7). Additionally, the resulting NSE shows more satisfactory results for baseflow than for peak flow due to the better PDM skill in reproducing the dry climate, whatever the rainfall-runoff simulation and the downscaling method (i.e. CDF-t-year or CDF-t-season).

During the PDM validation periods, a slight decrease in the model performance was observed except for region B and box A during the 1990-2005 and 1950-1972 time
HESSD

7, 9523-9565, 2010

\section{Coupling statistically downscaled GCM outputs with a basin-lake model}

M. Troin et al.

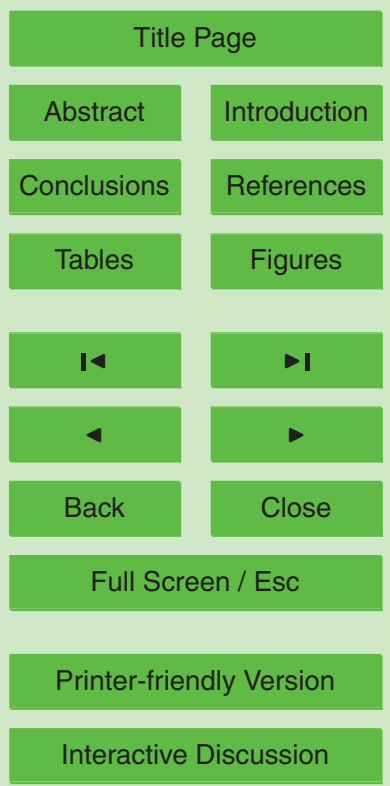


periods, respectively (Table 7). However, SWAT simulations using the boxes B and C with CDF-t-year still provided the most satisfying results (Table 7).

For each SWAT simulation over the 1950-2005 time period, the model generally reproduced seasonal and annual variations in runoff of the Sali-Dulce Basin (Fig. 5).

5 Whereas the monthly baseflow simulations driven by the downscaled reanalysis regions and LMDZ boxes were generally accurately reproduced, peak flows remained clearly overestimated. In particular, similar findings for consecutive years (1981-1982 and 1998-1999) were noticeable for SWAT simulations using the downscaled largescale data, especially for the region $B$, and the boxes $A$ and $C$ (Fig. 5).

\subsection{Comparison of lake level simulations}

Since, the Rio Sali-Dulce discharge was shown to be the main driver of the abrupt level rise observed in the 1970's in Laguna Mar Chiquita (Troin et al., 2010), we used the ten simulations of Rio Sali-Dulce discharges to replace the measured $Q_{\mathrm{R} 3}$ time series (Eq. 3). All the others components of the lake water balance model were derived from observations except for the lake evaporation which was estimated by the CRLE model (Troin et al., 2010).

Generally, the trends of the lake level fluctuations derived from the SWAT simulations using both reanalyses regions and LMDZ boxes were quite similar to the simulated reference curve except the lowstand in the early 1970's which is not well reproduced 20 (Fig. 6). It is noteworthy that this lowstand was also not fairly captured by the SWAT simulation using the two available observed meteorological data before 1972 (Table 1 and Fig. 6; Simulated curve-SWAT/observed data), which was attributed to the poor spatial representation of observed precipitation (Troin et al., 2010).

For the lake level simulations using SWAT forced by reanalyses in region $A$ and 25 LMDZ box A, a clear opposite trend was identified for the last highstand in the early 2000's (Fig. 6a and c). Additionnaly, a shift for the 1980's highstand in the lake level simulations was observed using reanalyses region $B$ and LMDZ boxes $B$ and $C$ (Fig. 6b, $\mathrm{d}$, and e). The lake level increase at the beginning of the 2000's is however well

HESSD

7, 9523-9565, 2010

\section{Coupling statistically downscaled GCM outputs with a basin-lake model}

M. Troin et al.

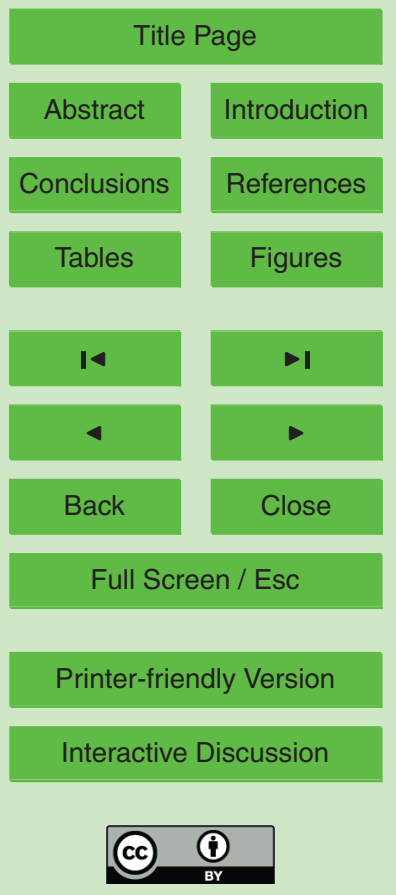


reproduced using reanalyses region $\mathrm{B}$, due to the high overestimation of the simulated peak flow during this period (Fig. 5b). Overall, the lake level trends obtained with the LMDZ boxes $B$ and $C$ for both CDF-t approaches were the most synchronous with the simulated reference curve (Troin et al., 2010) with one moderate highstand centered 5 at approximately 1960 followed by three major highstands centered at approximately 1985, 1994, and 2000.

\section{Discussion and conclusions}

\subsection{Relevance of downscaled climate variables for hydrological impact studies}

The reliability of downscaled climate variables from large-scale data-sets 10 (NCEP/NCAR reanalyses and LMDZ GCM) over SESA key regions as input to an integrated basin-lake model was illustrated in this study.

One important feature is the similarity of the simulated extreme hydrological events with the SWAT simulations using both downscaled reanalyses and LMDZ data (Fig. 5). The high peak flows observed in 1981 and 1982, 1998 and 2000 are indeed common to each simulation and are explained by high annual downscaled precipitation total $(\Delta P=+64 \%$ to $+120 \%)$ compared to $1950-2005$ average value. Can we attribute these peak flows to the SWAT model emphasizing abnormally wet years related to climate phenomena such as ENSO, which also coincided with observed and simulated lake level rises in Laguna Mar Chiquita (Fig. 6)? The fact that these higher peak flows are simulated using LMDZ forced with observed SSTs, suggest indeed such remote ENSO influence on the lake level fluctuation. However, even though many studies have shown a link between the increased regional precipitation and ENSO (Grimm et al., 2000; Pezzi and Cavalcanti, 2001; Paegle and Mo, 2002; Grimm, 2003), further investigations are needed to corroborate the potential teleconnection with the Laguna
HESSD

7, 9523-9565, 2010

Coupling statistically downscaled GCM outputs with a basin-lake model

M. Troin et al.

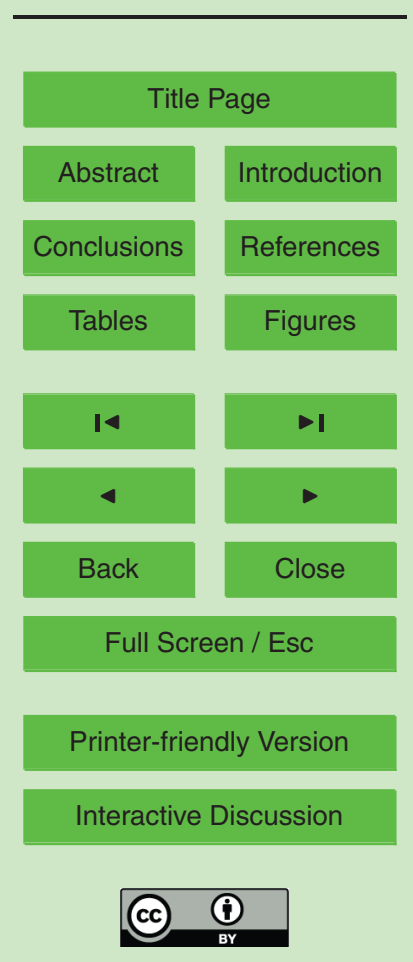




\subsection{Climate understanding: insights of an integrated basin-lake model}

An interesting feature is that the lake level trends are better simulated using downscaled LMDZ outputs compared to reanalyses, with the best results using LMDZ boxes $\mathrm{B}\left(15^{\circ}-25^{\circ} \mathrm{S} ; 55^{\circ}-65^{\circ} \mathrm{W}\right)$ and $\mathrm{C}\left(20^{\circ}-25^{\circ} \mathrm{S} ; 55^{\circ}-65^{\circ} \mathrm{W}\right)$. Compared to NCEP/NCAR 5 reanalyses the simulated variations of LMDZ precipitation driven by observed global SST only, is remarkably able to drive interdecadal lake level variations consistent with observations (Fig. 6). The best results obtained with data from regions at lower latitudes $\left(15^{\circ}-25^{\circ} \mathrm{S}\right)$ than the actual lake catchment, suggest that Laguna Mar Chiquita is mainly under tropical climate influences in agreement with a previous study based on observations (Troin et al., 2010).

It is indeed worth noting that SWAT simulations obtained with downscaled LMDZ variables allow reproducing accurately the key hydrological decadal cycles in the lake level as seen in observations, i.e., the 1956-1962, 1973-1990, 1991-1996, and 1997-2005 cycles, and the lake level highstands in the 1980's, 1990's, and 2000's. These features 15 would suggest that the lake level decadal variability is in connection with global oceanatmosphere variations, with the lake level highstands probably linked to extremes climatic events. More investigations are needed to evaluate the respective role of extreme events (i.e. intensity, amplitude, and frequency) and of low frequency climate variability (i.e. multi-decadal cycles) on the evolution and highstand persistence of the Laguna Mar Chiquita level (Sylvestre et al., 2010).

Questions still remain as for the lowstand in the early 1970's, which is not well reproduced in either simulation. It is important to point out that the overestimation of lake level lowstand is probably due to the poor spatial distribution of observed precipitation used to validate SWAT for the 1950-1972 time period (only two stations: Tucuman recorded at the Tucuman station (1966-1971: $\Delta P=+16 \%)$, and specificaly a wetter year in $1968(\Delta P=+72 \%)$, probably biased our results (Fig. 6) with a stronger local climatic influence as previously explained by (Troin et al., 2010). This might also be true for the lake level overestimation in 1970's in SWAT simulations derived from the

HESSD

7, 9523-9565, 2010

\section{Coupling statistically downscaled GCM outputs with a basin-lake model}

M. Troin et al.

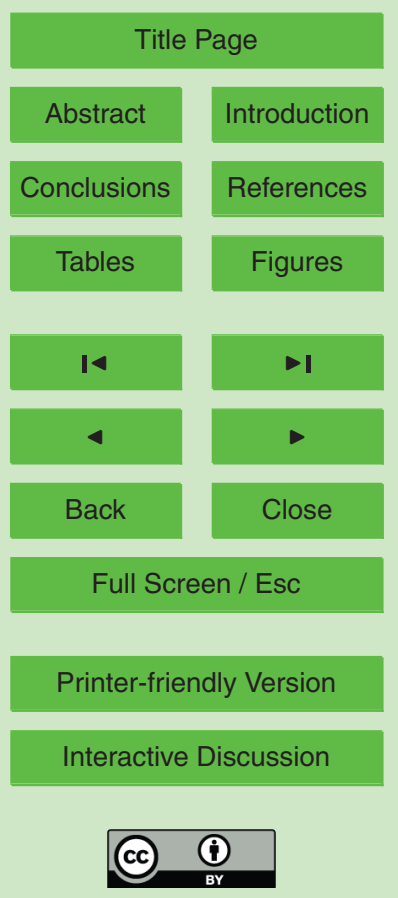


reanalyses or LMDZ outputs. Since the Tucuman station data were used for the downscaling, the relation between regional and global climatic variability could have been overshadowed by local climate extreme events. This discrepancy underlines the limitation of our modeling approach when the spatial distribution of field observation is too 5 poor. Even though more work is required to explore the hypothesis explaining such discrepancy, our results suggest that Laguna Mar Chiquita can be considered as an integrator of large-scale climate variability in this region of South America from interannual to decadal time scale.

To our knowledge, this study is one of the first to provide an integrated basin-lake 10 model forced by downscaled large-scale climate variables. This modeling approach may be used as a valuable tool for simulating future hydrological responses and for reconstructing past climate conditions, which will improve our understanding of climate variability in this region of South America.

Acknowledgements. The work presented was supported by a PhD grant from the French Min15 istry (Magali Troin), and benefited from funding from the French CNRS-INSU (PNEDC and LEFE-EVE programs, AMANCAY project) and from the French National Research Agency (program VMC, project ANR-06-VULN-010, ESCARSEL project). The work was also part of the CLARIS-LBP project (EC-FP7), ECOS-MINCYT (PA08U02, France-Argentina cooperation), and PIP 112-200801-00808 (CONICET). Mathieu Vrac has been partly funded by the GIS REGYNA project.

\section{References}

Arnold, J. G. and Allen, P. M.: Estimating hydrologic budgets for three Illinois watersheds, J. Hydrol., 176, 57-77, 1996.

Arnold, J. G., Srinivasan, R., Muttiah, R. S., and Williams, J. R.: Large area hydrologic mod1998.

Barros, V., Doyle, M., Gonzalez, M., Camilloni, I., Bejaran, R., and Caffera, R. M.: Climate

HESSD

7, 9523-9565, 2010

\section{Coupling statistically downscaled GCM outputs with a basin-lake model}

M. Troin et al.

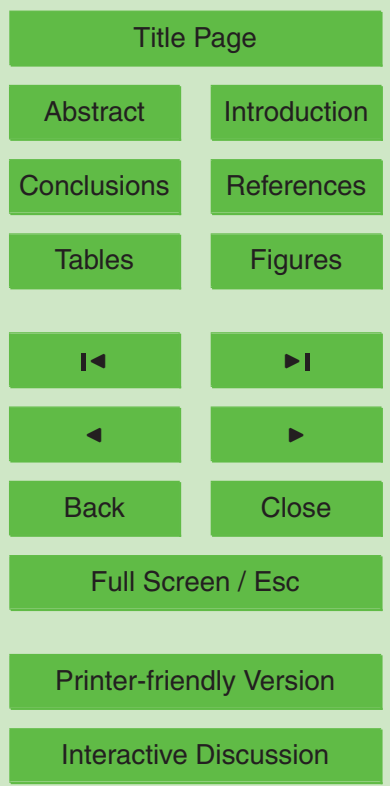


variability over subtropical South America and the South American monsonn: a review, Meteorologica, 27, 33-58, 2002.

Berbery, E. R. and Barros, V. R.: The hydrologic cycle of the La Plata basin in South America, J. Hydromet., 3, 630-645, 2003.

5 Bürger, G. and Chen, Y.: Regression-based downscaling of spatial variability for hydrologic applications, J. Hydrol., 311, 299-317, 2005.

Camilloni, I. and Barros, V.: Extreme discharge events in the Parana River and their climate forcing, J. Hydrol., 278, 94-106, 2003.

Chiew, F. H. S., Kirono, D. G. C., Kent, D. M., Frost, A. J., Charles, S. P., Timbal, B., Nguyen, K. C., and Fu, G.: Comparison of runoff modelled using rainfall from different downscaling methods for historical and future climates, J. Hydrol., 387, 10-23, 2010.

Déqué, M.: Frequency of precipitation and temperature extremes over France in an anthropogenic scenario: model results and statistical correction according to observed values, Global Planet. Change, 57, 16-26, 2007.

DosReis, R. J. and Dias, N. L.: Multi-season lake evaporation: energy-budget estimates and CRLE model assessment with limited meteorological observations, J. Hydrol., 208, 135-147, 1998.

Dufresne, J. L., Quaas, J., Boucher, O., Denvil, F., and Fairhead, L.: Contrasts in the effects on climate of anthropogenic sulfateaerosols between the 20th and the 21st century, Geophys.

20 Res. Lett., 32, L21703, doi:10.1029/2005GL023619, 2005.

Fowler, H. J., Blenkinsop, S., and Tebaldi, C.: Linking climate change modelling to impacts studies: recent advances in downscaling techniques for hydrological modelling, Int. J. Climatol., 27, 1547-1578, 2007.

Garcia, N. O. and Vargas, W. M.: The temporal climatic variability in the Rio de la Plata basin displayed by the river discharge, Climatic Change, 38, 359-379, 1998.

Garcia, N. O. and Mechoso, C. R.: Variability in the discharge of South American rivers and in climate, Hydrolog. Sci., 50, 459-478, 2005.

Gavier, G. I. and Bucher, E. H.: Deforestacion de las Sierras chicas de Cordoba (Argentina) en el periodo 1970-1997, Academia Nacional de Ciencas, Cordoba, Argentina, Miscelaneas, 101, 3-27, 2004.

Genta, J. L., Perez Iribarren, G., and Mechoso, C.: A recent increasing trend in the streamflow of rivers in southeastern South America, J. Climate, 11, 2858-2862, 1998.

Grimm, A. M., Barros, V. R., and Doyle, M. E.: Climate variability in southern South America
HESSD

7, 9523-9565, 2010

\section{Coupling statistically downscaled GCM outputs with a basin-lake model}

M. Troin et al.

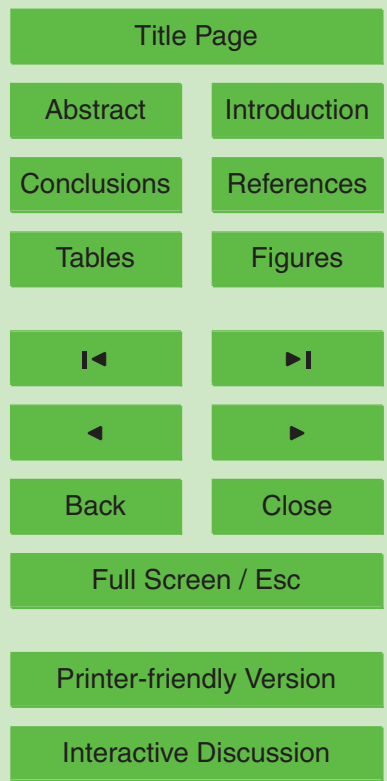

Interactive Discussion 
associated with El Niño and La Niña events, J. Climate, 13, 35-58, 2000.

Grimm, A. M.: The El Niño impact on the summer monsoon in Brazil: regional processes versus remote influences, J. Climate, 16, 263-280, 2003.

Hargreaves, G. H. and Samani, Z. A.: Reference crop evapotranspiration from temperature, $5 \quad$ Appl. Eng. Agric. 1, 96-99, 1985.

Hay, L., Clark, M. P., Wilby, R. L., Gutowski, W. J., Leavesley, G. H., Pan, Z., Arritt, R. W., and Takle, E. S.: Use of regional climate model output for hydrologic simulations, J. Hydrometeorol., 3, 571-590, 2002.

Hay, L. E. and Clark, M. P.: Use of a statistically and dynamically downscaled atmospheric model output for hydrologic simulations in three mountainous basins in the western United States, J. Hydrol., 482, 56-75, 2003.

Hillman, G.: Analysis y simulacion hidrologica del sistema de Mar Chiquita, Unpublished PhD, Universidad el Cordoba, Argentina, 160, 2003.

Hourdin, F., Musat, I., Bony, S., Braconnot, P., Codron, F., Dufresne, J. L., Fairhead, L., Filiberti, 15 M. A., Friedlingstein, P., Grandpeix, J. Y., Krinner, G., Le Van, P., Li, Z. X., and Lott, F.: The LMDZ4 general circulation model: climate performance and sensitivity to parametrized physics with emphasis on tropical convection, Clim. Dynam., 27, 787-813, 2006.

Huth, R., Kliegrova, S., and Metelka, L.: Non-linearity in statistical downscaling: does it bring an improvement for daily temperature in Europe?, Int. J. Climatol., 28(4), 465-477, 2008.

20

Kasahara, A.: Computational aspects of numerical modelsfor weather prediction and climate simulation, in: Methods in computational physics, edited by: Chang, J., vol 17, Academic, Amsterdam, 1-66, 1977.

Kröhling, D. M. and Iriondo, M.: Upper Quaternary palaeoclimates of the Mar Chiquita area, North Pampa, Argentina, Quatern. Int., 57-58, 149-163, 1999.

Labraga, J. C., Frumento, O., and Lopez, M.: The atmospheric water vapor cycle in South America and the tropospheric circulation, J. Climate, 13, 1899-1915, 2000.

Marti, O., Braconnot, P., Bellier, J., Benshila, R., Bony, S., Brockmann, P., Cadule, P., Caubel, A., Denvil, S., Dufresne, J. L., Fairhead, L., Filiberti, M. A., Foujols, M. A., Fichefet, T., Friedlingstein, P., Grandpeix, J. Y., Hourdin, F., Krinner, G., Lévy, C., Madec, G., Musat, I., de Nolbet, N., Polcher, J., and Talandier, C.: The new IPSL climate system model: IPSL-CM4, Paris, Institut Pierre Simon Laplace: 84, 2005.

Mamassis, N. and Koutsoyiannis, D.: Influence of atmospheric circulation types on space-time distribution of intense rainfall, J. Geophys. Res., 101, 267-276, 1996.
HESSD

7, 9523-9565, 2010

\section{Coupling statistically downscaled GCM outputs with a basin-lake model}

M. Troin et al.

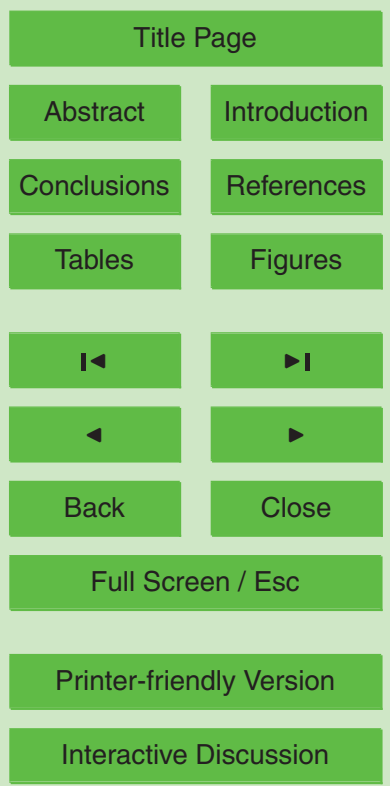

Interactive Discussion 
Michelangeli, P. A., Vrac, M., and Loukos, H.: Probabilistic downscaling approaches: application to wind cumulative distribution functions, Geophys. Res. Lett., 36, L11708, doi:10.1029/2009GL038401, 2009.

Morton, F. I.: Operational estimates of lake evaporation, J. Hydrol., 66, 77-100, 1983.

5 Nash, J. E. and Sutcliffe, J. V.: River flow forcasting through conceptual models part I - A discussion of principles, J. Hydrol., 10, 282-290, 1970.

Neitsch, S. L., Arnold, J. G., Kiniry, J. R., Williams, J. R., and King, K. W.: Soil and Water Assessment Tool Theoretical Documentation, Version 2000, Texas Water Resources Institutes, College Station, Texas, USA, 2002.

10 Paegle, J. N. and Mo, K. C.: Linkages between summer rainfall variability over South America and sea surface temperature anomalies, J. Climate, 15, 1389-1407, 2002.

Pasquini, A. I., Lecomte, K. L., Piovano, E. L., and Depetris, P. J.: Recent rainfall and runoff variability in central Argentina, Quatern. Int., 158, 127-139, 2006.

Pezzi, L. P. and Cavalcanti, I. F. A.: The relative importance of ENSO and tropical Atlantic sea 15 surface temperature anomalies for seasonal precipitation over South America: a numerical study, Clim. Dynam., 17, 205-212, 2001.

Piovano, E. L., Damatto Moreira, S., and Ariztegui, D.: Recent environmental changes in Laguna Mar Chiquita (central Argentina): a sedimentary model for a highlty variable saline lake, Sedimentology, 49, 1371-1384, 2002.

20 Planchon, O. and Rosier, K.: Variabilité des régimes pluviométriques dans le nord-ouest de l'Argentine: problèmes posés et analyse durant la deuxième moitié du vingtième siècle, Annales de l'Association Internationale de Climatologie, 2, 55-76, 2005.

Prudhomme, C., Reynard, N., and Crooks, S.: Downscaling of global climate models for flood frequency analysis: where are we now?, Hydrol. Process., 16, 1137-1150, 2002.

Rayner, N. A., Parker, D. E., Horton, E. B., Folland, C. K., Alexander, L. V., Rowell, D. P., Kent, E. C., and Kaplan, A.: Global analyses of sea surface temperature, sea ice, and night marine air temperature since the late nineteenth century, J. Geophys. Res., 108(D14), 4407, doi:10.1209/2002JD002670, 2003.

Salathé, E. P.: Comparison of various precipitation downscaling methods for the simulation of streamflow in a rainshadow river basin, Int. J. Climatol., 23, 887-901, 2003.

SCS (Soil Conservation Service): National Engineering Handbook, Section 4, US Department of Agriculture, Washington, DC, 1972.

Sylvestre, F., Khodri, M., Piovano, P., Vallet-Coulomb, C., Troin, M., Ronchail, J., Brewer, S.,
HESSD

7, 9523-9565, 2010

\section{Coupling statistically downscaled GCM outputs with a basin-lake model}

M. Troin et al.

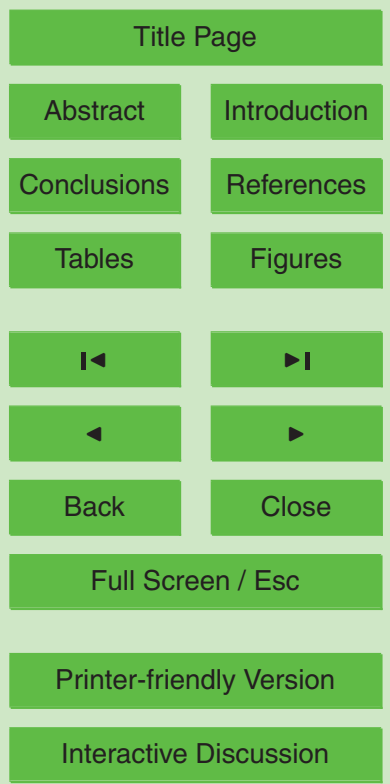


and Ariztegui, D.: The 1970's unprecedented wet phase over the last millenium revealed by lacustrine archives from subtropicak plains of South America: the role of tropical oceans progressive warmin, in preparation, 2010.

Tisseuil, C., Vrac, M., Lek, S., and Wade, A. J.: Direct statistical downscaling of river flows, J. Hydrol., 385, 279-291, 2010.

Troin, M., Vallet-Coulomb, C., Sylvestre, F., and Piovano, E.: Hydrological modelling of a closed lake (Laguna Mar Chiquita, Argentina) in the context of 20th century climatic changes, J. Hydrol., 383, 233-244, 2010.

Troin, M., Vallet-Coulomb, C., Piovano, E., and Sylvestre, F.: Hydrological impacts of climate change: assessment of a basin-lake model applicability using contrasting climatic conditions in subtropical South America, Water Resour. Res., in revision, 2010.

Vrac, M., Marbaix, P., Paillard, D., and Naveau, P.: Non-linear statistical downscaling of present and LGM precipitation and temperatures over Europe, Clim. Past, 3, 669-682, doi:10.5194/cp-3-669-2007, 2007a.

15 Vrac, M., Stein, M., and Hahoe, K.: Statistical downscaling of precipitation through nonhomogeneous stochastic weather typing, Clim. Res., 34, 169-184, 2007b.

Vrac, M. and Naveau, P.: Stochastic downscaling of precipitation: from dry events to heavy rainfalls, Water Resour. Res., 43, W07402, doi:10.1029/2006WR005308, 2007.

Wilby, R. L., Hay, L. E., and Leavesley, G. H.: A Comparison of Downscaled and Raw GCM

20 Output: implications for Climate Change Scenarios in the San Juan River Basin, Colorado, J. Hydrol., 225, 67-91, 1999.

Wilby, R. L., Conway, D., and Jones, P. D.: Prospects for downscaling seasonal precipitation variability using conditioned weather generator parameters, Hydrol. Process., 16, 12151234, 2002.

Wilks, D. S. and Wilby, R. L.: The weather generation game: a review of stochastic weather models, Prog. Phys. Geog., 23, 329-357, 1999.

Wood, A. W., Leung, L. R., Sridhar, V., and Lettenmaier, D. P.: Hydrologic implications of dynamical and statistical approaches to downscaling climate model outputs, Clim. Change, 62, 189-216, 2004.

30 Xu, C. Y.: From GCMs to river flow: a review of downscaling methods and hydrologic modelling approaches, Prog. Phys. Geog., 23, 229-249, 1999.

Zhou, J. and Lau, K. M.: Does a monsoon climate exist over South America?, J. Climate, 11, 1020-1040, 1998.
HESSD

7, 9523-9565, 2010

Coupling statistically downscaled GCM

outputs with a basin-lake model

M. Troin et al.

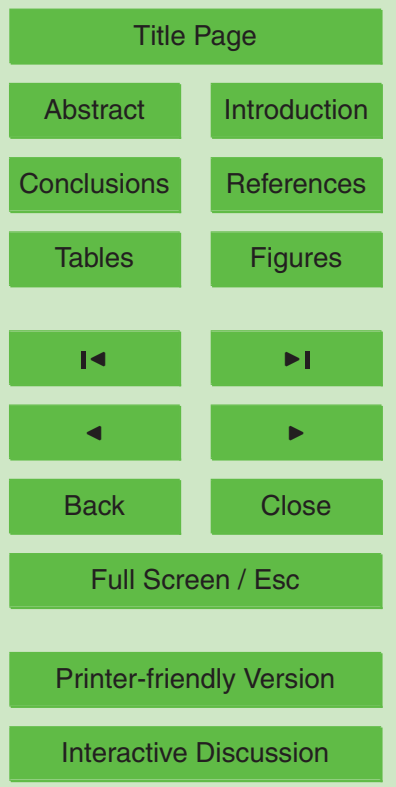




\section{HESSD}

7, 9523-9565, 2010

Coupling statistically downscaled GCM

outputs with a basin-lake model

M. Troin et al.

Table 1. The name, location, and main characteristics of the six meteorological stations.

\begin{tabular}{|c|c|c|c|c|c|c|c|c|c|c|c|c|}
\hline & Station & $\begin{array}{r}\text { Elevation } \\
(\mathrm{m})\end{array}$ & $\begin{array}{r}\text { Latitude } \\
\text { (S) }\end{array}$ & $\begin{array}{r}\text { Longitude } \\
\text { (W) }\end{array}$ & \multicolumn{3}{|c|}{$\begin{array}{l}\text { 1950-1972 time period } \\
\text { (no missing data) }\end{array}$} & \multicolumn{5}{|c|}{ 1973-2005 time period } \\
\hline 1 & Lules & 950 & -26.21 & -65.21 & - & - & - & 1596 & 8 & 14.3 & 26.8 & 25 \\
\hline 2 & Tucuman & 455 & -26.85 & -65.09 & 997 & 13.8 & 26.1 & 980 & 25 & 14.2 & 26.5 & 26 \\
\hline 3 & Las Canas & 1300 & -27.24 & -65.59 & - & - & - & 1084 & 3 & 13.9 & 27.7 & 20 \\
\hline 6 & Catamarca & 464 & -28.35 & -65.77 & - & - & - & 513 & 6 & 14.3 & 28.3 & 0.5 \\
\hline
\end{tabular}

Title Page

Abstract

Introduction

Conclusions

References

Tables

Figures

14

Back

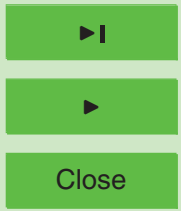

Full Screen / Esc

Printer-friendly Version

Interactive Discussion 


\section{HESSD}

7, 9523-9565, 2010

Coupling statistically downscaled GCM

outputs with a basin-lake model

M. Troin et al.

Table 2. The name, location, and main characteristics of the river discharge station during the 1950-2005 time period.

\begin{tabular}{llllllll}
\hline & $\begin{array}{l}\text { River discharge } \\
\text { station }\end{array}$ & $\begin{array}{l}\text { Latitude } \\
(\mathrm{S})\end{array}$ & $\begin{array}{l}\text { Longitude } \\
(\mathrm{W})\end{array}$ & $\begin{array}{l}\text { Catchment } \\
\text { area }\left(\mathrm{km}^{2}\right)\end{array}$ & $\begin{array}{l}\text { Average } \\
\text { value } \\
\left(\mathrm{m}^{3} / \mathrm{s}\right)\end{array}$ & $\begin{array}{l}\text { Specific } \\
\text { discharge } \\
(\mathrm{mm} / \text { year })\end{array}$ & $\begin{array}{l}\text { Proportion of } \\
\text { monthly missing } \\
\text { data }(\%)\end{array}$ \\
\hline R3b (Rio Sali-Dulce) & Hondo & $27^{\circ} 30^{\prime}$ & $64^{\circ} 52^{\prime}$ & 23810 & 126 & 167 & 0 \\
\hline
\end{tabular}

Title Page

Abstract Introduction

Conclusions

References

Tables

Figures

14

4

Back

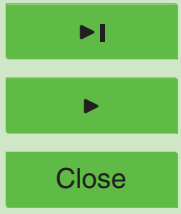

Full Screen / Esc

Printer-friendly Version

Interactive Discussion 
Table 3. Downscaling method calibration fit expressed in terms of the percentage of explained variance $(E \%)$ in daily maximum and minimum temperatures and the proportion of dry and wet days occurrences in daily precipitation for the two NCEP/NCAR reanalyses regions for 19731989 (Bracket values referred to the proportion of dry and wet days occurrences in observed daily precipitation).

\begin{tabular}{|c|c|c|c|c|c|c|}
\hline \multirow[t]{2}{*}{ Data source } & \multirow[t]{2}{*}{$\begin{array}{l}\text { PDM } \\
\text { approach }\end{array}$} & \multirow[t]{2}{*}{ Period } & \multicolumn{2}{|c|}{$\begin{array}{c}\text { Proportion of } \\
\text { precipitation occurence }\end{array}$} & \multirow[t]{2}{*}{$\begin{array}{l}\text { Maximum } \\
\text { temperature }\end{array}$} & \multirow[t]{2}{*}{$\begin{array}{l}\text { Minimum } \\
\text { temperature }\end{array}$} \\
\hline & & & Dry day & Wet day & & \\
\hline \multirow{5}{*}{ Region A } & \multirow{5}{*}{ CDF-t-year } & year & $83(66)$ & $17(34)$ & 52 & 75 \\
\hline & & DJF & $54(45)$ & $46(55)$ & 38 & 40 \\
\hline & & MAM & $86(61)$ & $14(39)$ & 47 & 62 \\
\hline & & JJA & $100(85)$ & $0(15)$ & 41 & 26 \\
\hline & & SON & $92(71)$ & $8(29)$ & 47 & 63 \\
\hline \multirow{5}{*}{ Region A } & \multirow{5}{*}{ CDF-t-season } & year & $78(66)$ & $22(34)$ & 64 & 74 \\
\hline & & DJF & $53(45)$ & $47(55)$ & 39 & 40 \\
\hline & & MAM & $83(61)$ & $17(39)$ & 51 & 61 \\
\hline & & JJA & $95(85)$ & $5(15)$ & 48 & 26 \\
\hline & & SON & $80(71)$ & $20(29)$ & 51 & 62 \\
\hline \multirow{5}{*}{ Region B } & \multirow{5}{*}{ CDF-t-year } & year & $82(66)$ & $18(34)$ & 37 & 59 \\
\hline & & DJF & $67(45)$ & $33(55)$ & 10 & 12 \\
\hline & & MAM & $82(61)$ & $18(39)$ & 37 & 55 \\
\hline & & JJA & $97(85)$ & $3(15)$ & 21 & 33 \\
\hline & & SON & $82(71)$ & $18(29)$ & 27 & 36 \\
\hline \multirow{5}{*}{ Region B } & \multirow{5}{*}{ CDF-t-season } & year & $78(66)$ & $22(34)$ & 48 & 65 \\
\hline & & DJF & $62(45)$ & $38(55)$ & 10 & 11 \\
\hline & & MAM & $78(61)$ & $22(39)$ & 40 & 58 \\
\hline & & JJA & $95(85)$ & $5(15)$ & 25 & 37 \\
\hline & & SON & $78(71)$ & $22(29)$ & 27 & 39 \\
\hline
\end{tabular}

HESSD

7, 9523-9565, 2010

Coupling statistically downscaled GCM

outputs with a basin-lake model

M. Troin et al.

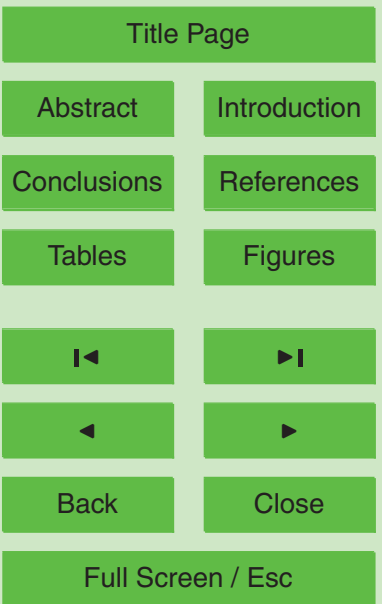

Printer-friendly Version

Interactive Discussion 
Table 4. Downscaling method calibration fit expressed in terms of the percentage of explained variance $(E \%)$ in daily maximum and minimum temperatures and the proportion of dry and wet days occurrences in daily precipitation for the three LMDZ grid-boxes for 19731989 (Bracket values referred to the proportion of dry and wet days occurrences in observed daily precipitation).

\begin{tabular}{|c|c|c|c|c|c|c|}
\hline \multirow[t]{2}{*}{$\begin{array}{l}\text { Data } \\
\text { source }\end{array}$} & \multirow[t]{2}{*}{$\begin{array}{l}\text { PDM } \\
\text { approach }\end{array}$} & \multirow[t]{2}{*}{ Period } & \multicolumn{2}{|c|}{$\begin{array}{c}\text { Proportion of } \\
\text { Precipitation occurence }\end{array}$} & \multirow[t]{2}{*}{$\begin{array}{l}\text { Maximum } \\
\text { temperature }\end{array}$} & \multirow[t]{2}{*}{$\begin{array}{l}\text { Minimum } \\
\text { temperature }\end{array}$} \\
\hline & & & Dry day & Wet day & & \\
\hline \multirow{5}{*}{ Box A } & \multirow{5}{*}{ CDF-t-year } & year & $81(66)$ & $19(34)$ & 47 & 61 \\
\hline & & DJF & $52(45)$ & $48(55)$ & 10 & 20 \\
\hline & & MAM & $82(61)$ & $18(39)$ & 30 & 40 \\
\hline & & JJA & 97 (85) & $3(15)$ & 15 & 21 \\
\hline & & SON & $92(71)$ & $8(29)$ & 17 & 35 \\
\hline \multirow{5}{*}{ Box A } & \multirow{5}{*}{ CDF-t-season } & year & $76(66)$ & $24(34)$ & 45 & 57 \\
\hline & & DJF & $52(45)$ & $48(55)$ & 10 & 20 \\
\hline & & MAM & 77 (61) & 23 (39) & 26 & 27 \\
\hline & & JJA & $92(85)$ & 8 (15) & 14 & 21 \\
\hline & & SON & $84(71)$ & $16(29)$ & 17 & 29 \\
\hline \multirow{5}{*}{ Box B } & \multirow{5}{*}{ CDF-t-year } & year & $76(66)$ & $24(34)$ & 37 & 59 \\
\hline & & DJF & $25(45)$ & $75(55)$ & 10 & 20 \\
\hline & & MAM & $85(61)$ & 15 (39) & 25 & 37 \\
\hline & & JJA & $98(85)$ & 2 (15) & 13 & 15 \\
\hline & & SON & $97(71)$ & $3(29)$ & 14 & 28 \\
\hline \multirow{5}{*}{ Box B } & \multirow{5}{*}{ CDF-t-season } & year & $77(66)$ & $23(34)$ & 40 & 55 \\
\hline & & DJF & $42(45)$ & $58(55)$ & 12 & 10 \\
\hline & & MAM & $81(61)$ & 19 (39) & 22 & 29 \\
\hline & & JJA & $96(85)$ & $4(15)$ & 13 & 15 \\
\hline & & SON & $89(71)$ & $11(29)$ & 19 & 27 \\
\hline \multirow{5}{*}{ Box C } & \multirow{5}{*}{ CDF-t-year } & year & $77(66)$ & $23(34)$ & 39 & 58 \\
\hline & & DJF & $33(45)$ & $67(55)$ & 10 & 18 \\
\hline & & MAM & $83(61)$ & $17(39)$ & 25 & 36 \\
\hline & & JJA & $98(85)$ & $2(15)$ & 12 & 14 \\
\hline & & SON & $95(71)$ & $5(29)$ & 18 & 29 \\
\hline \multirow{5}{*}{ Box C } & \multirow{5}{*}{ CDF-t-season } & year & $77(66)$ & $23(34)$ & 40 & 59 \\
\hline & & DJF & $45(45)$ & $55(55)$ & 12 & 19 \\
\hline & & MAM & $81(61)$ & 19 (39) & 21 & 28 \\
\hline & & JJA & $93(85)$ & 7 (15) & 14 & 14 \\
\hline & & SON & $87(71)$ & $13(29)$ & 19 & 28 \\
\hline
\end{tabular}

\section{HESSD}

7, 9523-9565, 2010

\section{Coupling statistically downscaled GCM outputs with a basin-lake model}

M. Troin et al.

\section{Title Page}

\section{Abstract}

Introduction

Conclusions

Tables

References

Figures

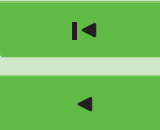

Back

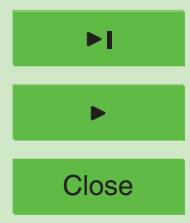

Full Screen / Esc

Printer-friendly Version

Interactive Discussion 


\section{HESSD}

7, 9523-9565, 2010

Coupling statistically downscaled GCM

outputs with a

Table 5. Comparison of downscaling PDM approaches outputs and observed (six meteorological stations) precipitation, maximum and minimum temperatures for the validation (1990-2005).

\begin{tabular}{|c|c|c|c|c|c|c|c|c|c|}
\hline \multirow[t]{2}{*}{ Data source } & \multirow[t]{2}{*}{ PDM approach } & \multicolumn{4}{|c|}{ Precipitation (mm) } & \multicolumn{2}{|c|}{$\begin{array}{c}\text { Maximum } \\
\text { temperature }\left({ }^{\circ} \mathrm{C}\right)\end{array}$} & \multicolumn{2}{|c|}{$\begin{array}{c}\text { Minimum } \\
\text { temperature }\left({ }^{\circ} \mathrm{C}\right)\end{array}$} \\
\hline & & Mean & SD & $\%$ Wet & Total & Mean & SD & Mean & SD \\
\hline \multirow{2}{*}{ Region A } & CDF-t-year & 0.9 & 6.8 & 8 & 343 & 26.9 & 7.1 & 14.0 & 6.1 \\
\hline & CDF-t-season & 1.5 & 8.6 & 16 & 563 & 27 & 7.2 & 14.1 & 6.5 \\
\hline \multirow{2}{*}{ Region B } & CDF-t-year & 2.4 & 10.4 & 19 & 872 & 26.6 & 6.7 & 14.3 & 6.7 \\
\hline & CDF-t-season & 3.0 & 11.7 & 24 & 1092 & 26.5 & 6.5 & 14.2 & 6.6 \\
\hline \multirow[b]{2}{*}{ Box A } & CDF-t-year & 2.3 & 10.1 & 20 & 856 & 27 & 6.6 & 14.5 & 6.5 \\
\hline & CDF-t-season & 2.4 & 10.1 & 21 & 859 & 27 & 6.6 & 14.5 & 6.5 \\
\hline \multirow{2}{*}{ Box B } & CDF-t-year & 2.2 & 9.6 & 21 & 797 & 27.1 & 7.1 & 14.6 & 6.6 \\
\hline & CDF-t-season & 2.1 & 9.7 & 19 & 774 & 27.3 & 6.9 & 14.7 & 6.5 \\
\hline \multirow[b]{2}{*}{ Box $C$} & CDF-t-year & 2.2 & 9.8 & 19 & 791 & 27.1 & 6.9 & 14.6 & 6.5 \\
\hline & CDF-t-season & 2.2 & 9.9 & 20 & 817 & 27.2 & 6.7 & 14.6 & 6.5 \\
\hline Observed & & 2.2 & 5.7 & 30 & 792 & 27.6 & 6.3 & 14 & 6.2 \\
\hline
\end{tabular}

\section{basin-lake model}

M. Troin et al.

Title Page

Abstract

Introduction

Conclusions

Tables

References

Figures

14

Back

Close

Full Screen / Esc

Printer-friendly Version

Interactive Discussion 


\section{HESSD}

7, 9523-9565, 2010

\section{Coupling statistically downscaled GCM \\ outputs with a \\ basin-lake model}

Table 6. Comparison of downscaling PDM approaches outputs and observed precipitation, maximum and minimum temperatures for the validation (1950-1972) at the two and six (bracket values) meteorological stations.

M. Troin et al.

\begin{tabular}{|c|c|c|c|c|c|c|c|c|c|}
\hline \multirow[t]{2}{*}{ Data source } & \multirow[t]{2}{*}{ PDM approach } & \multicolumn{4}{|c|}{ Precipitation (mm) } & \multicolumn{2}{|c|}{$\begin{array}{c}\text { Maximum } \\
\text { temperature }\left({ }^{\circ} \mathrm{C}\right)\end{array}$} & \multicolumn{2}{|c|}{$\begin{array}{c}\text { Minimum } \\
\text { temperature }\left({ }^{\circ} \mathrm{C}\right)\end{array}$} \\
\hline & & Mean & SD & $\%$ Wet & Total & Mean & SD & Mean & SD \\
\hline \multirow{2}{*}{ Region A } & CDF-t-year & $0.9(1.3)$ & $8.2(8.1)$ & $5(13)$ & $337(488)$ & $26.2(26.3)$ & $6.4(6.5)$ & $14.2(14.3)$ & 5.9 (5.9) \\
\hline & CDF-t-season & $1.7(2.2)$ & $10.1(9.9)$ & $12(21)$ & $636(794)$ & $26.1(26.3)$ & $6.5(6.6)$ & $14.1(14.2)$ & $5.9(5.9)$ \\
\hline \multirow[b]{2}{*}{ Region B } & CDF-t-year & $1.5(1.8)$ & $10.8(9.6)$ & $8(15)$ & $550(666)$ & $26.6(26.7)$ & $6.3(6.4)$ & $14.3(14.5)$ & $6.2(6.3)$ \\
\hline & CDF-t-season & $1.6(2.2)$ & $10.9(10.5)$ & $9(20)$ & 595 (795) & $26.4(26.5)$ & $6.3(6.4)$ & $14.1(14.2)$ & $6.1(6.1)$ \\
\hline \multirow[b]{2}{*}{ Box A } & CDF-t-year & $1.3(1.7)$ & $9.3(8.2)$ & $9(17)$ & $465(615)$ & $26.6(26.6)$ & $6.5(6.5)$ & $14.0(14.1)$ & $6.3(6.4)$ \\
\hline & CDF-t-season & $1.5(2.2)$ & $9.5(9.3)$ & $11(20)$ & $559(800)$ & $26.6(26.6)$ & $6.5(6.5)$ & $13.9(14.0)$ & $6.3(6.3)$ \\
\hline \multirow[b]{2}{*}{ Box B } & CDF-t-year & $1.8(2.6)$ & $11.5(11.2)$ & $10(22)$ & $665(948)$ & $26.6(26.7)$ & $6.9(6.9)$ & $14.0(14.1)$ & $6.4(6.5)$ \\
\hline & CDF-t-season & $1.7(2.5)$ & $11.1(11.1)$ & $8(20)$ & $638(911)$ & $26.7(26.8)$ & $6.7(6.7)$ & $14.0(14.2)$ & $6.4(6.4)$ \\
\hline \multirow{2}{*}{ Box C } & CDF-t-year & $1.6(2.4)$ & $10.7(10.4)$ & $9(20)$ & $592(881)$ & $26.6(26.6)$ & $6.7(6.7)$ & $14.0(14.1)$ & $6.3(6.3)$ \\
\hline & CDF-t-season & $1.9(2.6)$ & $11.6(11.2)$ & $11(20)$ & $681(933)$ & $26.6(26.7)$ & $6.6(6.6)$ & $14.0(14.2)$ & $6.3(6.3)$ \\
\hline Observed & & 2 & 5.9 & 24 & 740 & 27.1 & 6.5 & 13.7 & 6.4 \\
\hline
\end{tabular}

Title Page

Abstract

Introduction

Conclusions

References

Tables

Figures

14

4

Back

Close

Full Screen / Esc

Printer-friendly Version

Interactive Discussion 
Table 7. SWAT model performance during PDM calibration and validation periods for each rainfall-runoff simulations.

\begin{tabular}{|c|c|c|c|}
\hline PDM calibration period (1973-1989) & NSE & NSE peak flow & NSE baseflow \\
\hline Region A CDF-t-year & 0.17 & 0.10 & 0.37 \\
\hline Region A CDF-t-season & 0.26 & 0.12 & 0.53 \\
\hline Region B CDF-t-year & 0.10 & 0.03 & 0.11 \\
\hline Region B CDF-t-season & 0.08 & 0.05 & 0.10 \\
\hline Box A CDF-t-year & 0.17 & 0.06 & 0.10 \\
\hline Box A CDF-t-season & 0.14 & 0.05 & 0.09 \\
\hline Box B CDF-t-year & 0.42 & 0.25 & 0.27 \\
\hline Box B CDF-t-season & 0.34 & 0.19 & 0.21 \\
\hline Box C CDF-t-year & 0.45 & 0.24 & 0.29 \\
\hline Box C CDF-t-season & 0.38 & 0.19 & 0.21 \\
\hline PDM validation period (1990-2005) & NSE & NSE peak flow & NSE baseflow \\
\hline Region A CDF-t-year & 0.08 & 0.04 & 0.06 \\
\hline Region A CDF-t-season & 0.09 & 0.05 & 0.07 \\
\hline Region B CDF-t-year & 0.15 & 0.10 & 0.35 \\
\hline Region B CDF-season & 0.18 & 0.09 & 0.44 \\
\hline Box A CDF-t-year & 0.09 & 0.05 & 0.06 \\
\hline Box A CDF-t-season & 0.08 & 0.01 & 0.10 \\
\hline Box B CDF-t-year & 0.33 & 0.24 & 0.36 \\
\hline Box B CDF-t-season & 0.30 & 0.19 & 0.43 \\
\hline Box C CDF-t-year & 0.23 & 0.18 & 0.29 \\
\hline Box C CDF-t-season & 0.21 & 0.17 & 0.45 \\
\hline PDM validation period (1950-1972) & NSE & NSE peak flow & NSE baseflow \\
\hline Region A CDF-t-year & 0.12 & 0.05 & 0.12 \\
\hline Region A CDF-t-season & 0.10 & 0.04 & 0.08 \\
\hline Region B CDF-t-year & 0.05 & 0.03 & 0.05 \\
\hline Region B CDF-t-season & 0.04 & 0.03 & 0.05 \\
\hline Box A CDF-t-year & 0.26 & 0.10 & 0.23 \\
\hline Box A CDF-t-season & 0.26 & 0.10 & 0.19 \\
\hline Box B CDF-t-year & 0.38 & 0.26 & 0.28 \\
\hline Box B CDF-t-season & 0.37 & 0.26 & 0.29 \\
\hline Box C CDF-t-year & 0.38 & 0.21 & 0.22 \\
\hline Box C CDF-t-season & 0.38 & 0.25 & 0.27 \\
\hline
\end{tabular}

\section{HESSD}

7, 9523-9565, 2010

Coupling statistically downscaled GCM

outputs with a basin-lake model

M. Troin et al.

Title Page

\section{Abstract}

Introduction

Conclusions

References

Tables

Figures

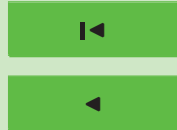

Back

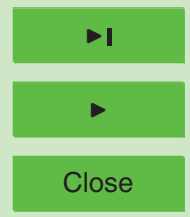

Full Screen / Esc

Printer-friendly Version

Interactive Discussion 


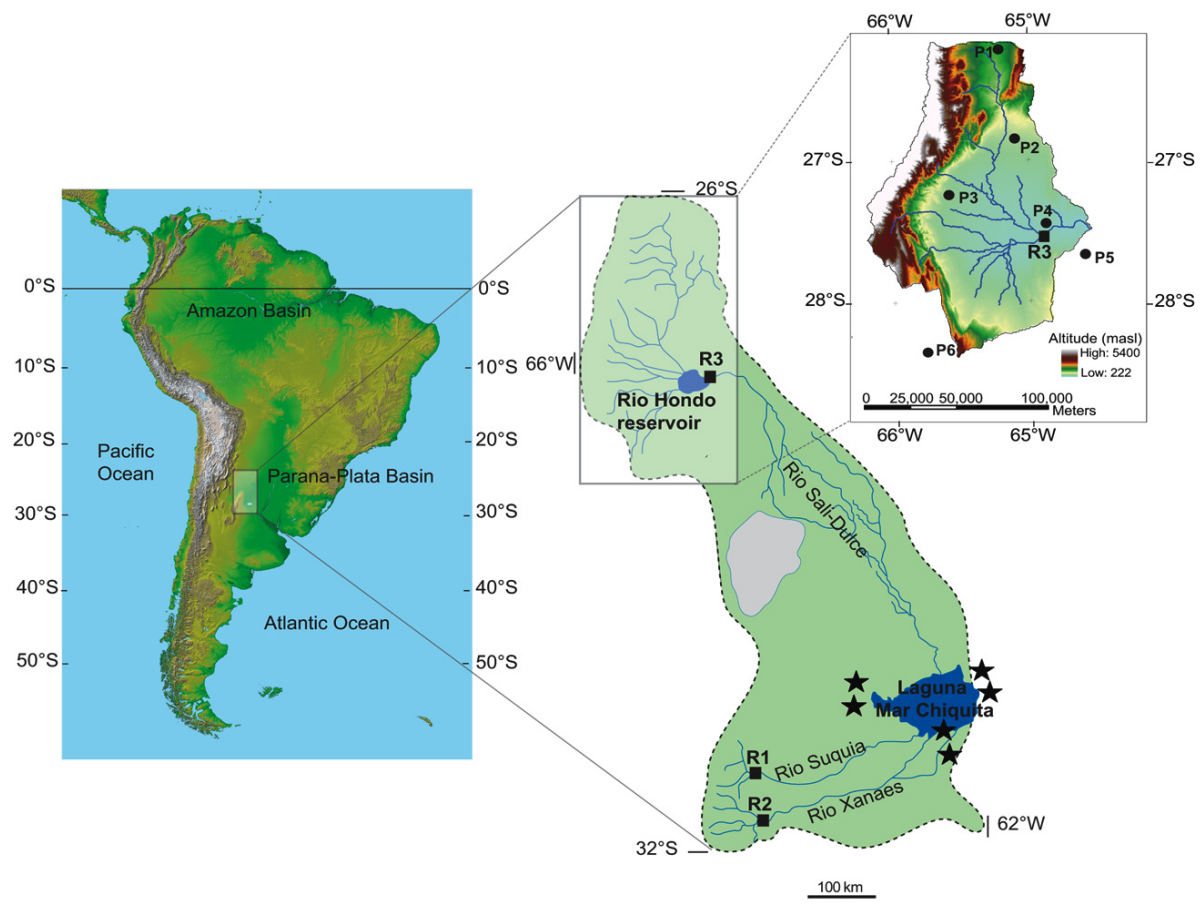

Fig. 1. Location of Laguna Mar Chiquita basin at the west of the Paraná-Plata Basin. The enlarged view shows the Sali-Dulce Basin in the northern part of the lake basin. Data used for the rainfall-runoff model come from meteorological stations 1 to 6 and gauging stations R3 at the Rio Hondo reservoir outlet. Data used for the lake water balance model (Troin et al., 2010) come from 6 meteorological stations around the lake (black stars) and 3 gauging stations (R1, R2, R3).
HESSD

7, 9523-9565, 2010

Coupling statistically downscaled GCM

outputs with a basin-lake model

M. Troin et al.

\section{Title Page}

\section{Abstract}

Conclusions

Tables

14

4

Back
Introduction

References

Figures

$\rightarrow$

$>$

Close
Full Screen / Esc

Printer-friendly Version

Interactive Discussion 


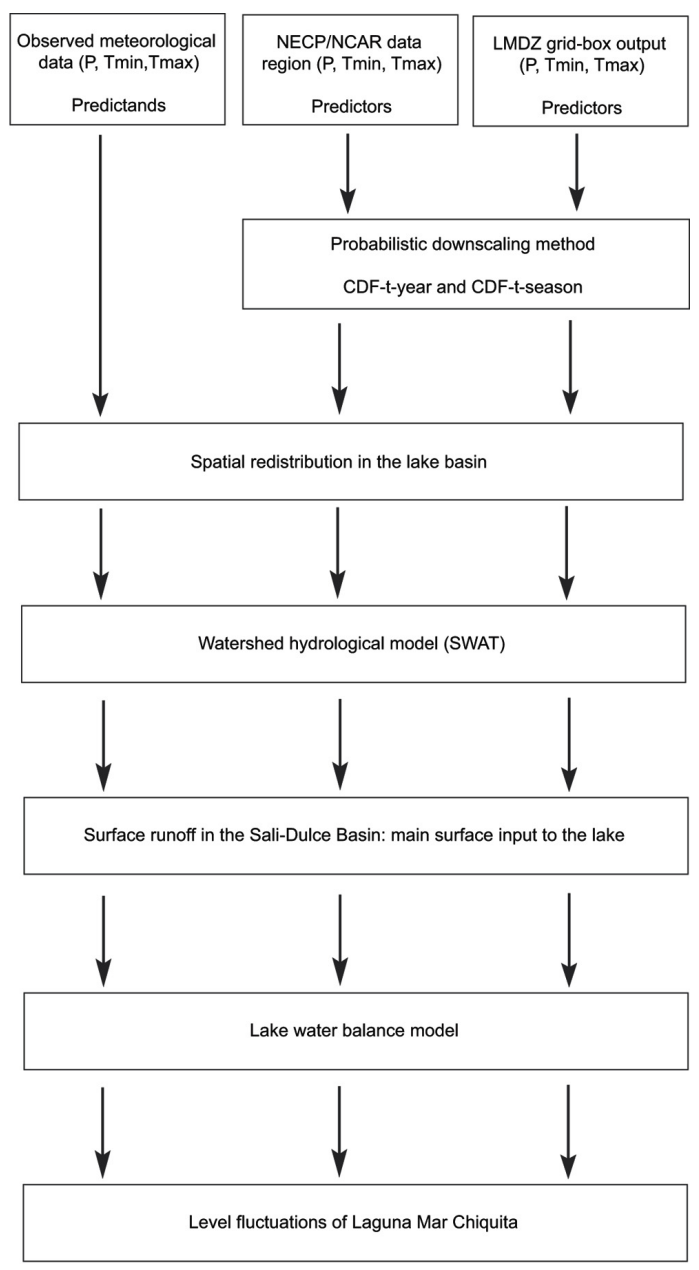

HESSD

7, 9523-9565, 2010

Coupling statistically downscaled GCM

outputs with a basin-lake model

M. Troin et al.

Title Page

Abstract

Introduction

Conclusions

References

Tables

Figures

14

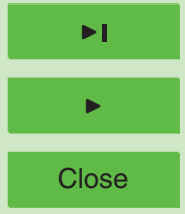

Back

Full Screen / Esc

Printer-friendly Version

Fig. 2. Methods for generating lake level simulations for Laguna Mar Chiquita.

Interactive Discussion 
(A1)

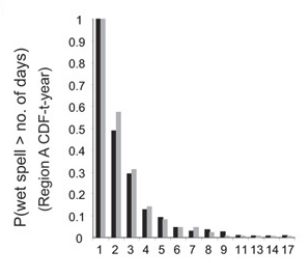

(B1)

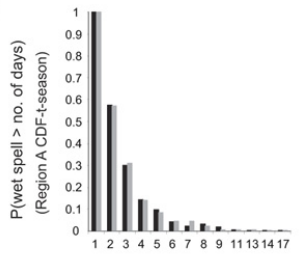

(C1)

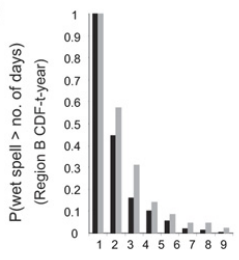

(D1)

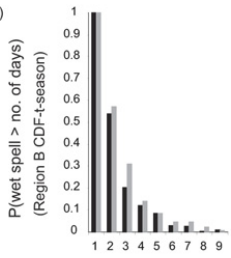

(A2)
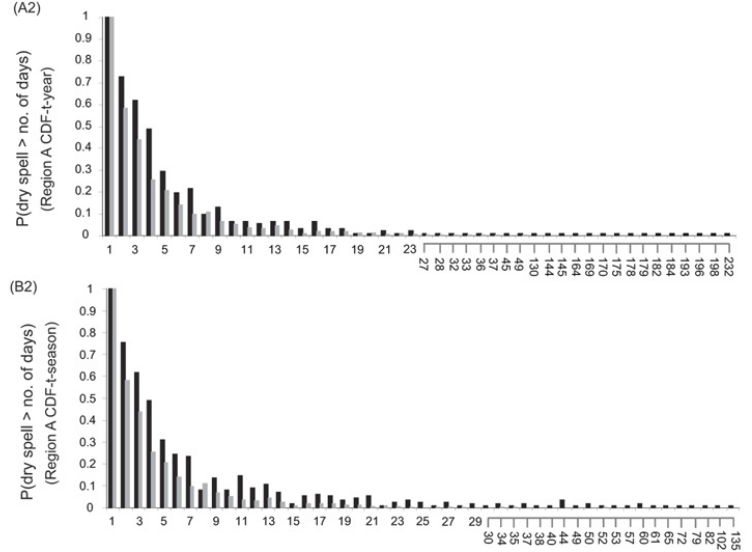

(C2)

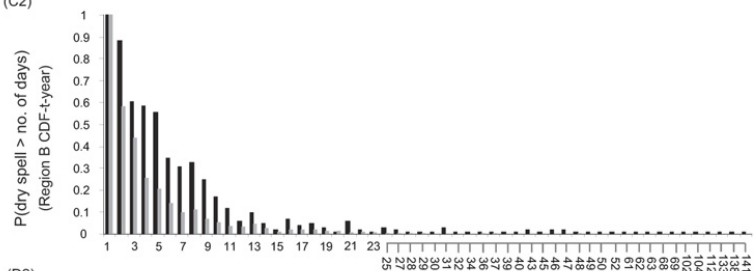

(D2)

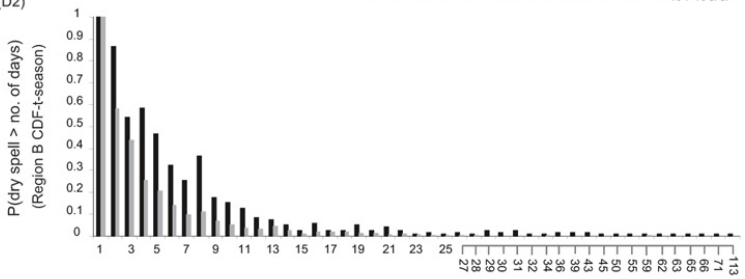

HESSD

7, 9523-9565, 2010

Coupling statistically downscaled GCM

outputs with a basin-lake model

M. Troin et al.

\section{Title Page}

\section{Abstract}

Introduction

Conclusions

References

Tables

Figures

14

$\rightarrow 1$

4

Back

Close

Full Screen / Esc

Fig. 3. Probabilities of duration of wet (first column) and dry (second column) spells for precipitation pattern-based simulated (black) and observed (grey) precipitation during the PDM 1973-1989 calibration period for (A) NCEP/NCAR region A by CDF-t-year, (B) downscaled NCEP/NCAR region A by CDF-t-season, (C) downscaled NCEP/NCAR region B by CDF-tyear, and (D) downscaled NCEP/NCAR region B by CDF-t-season.

Printer-friendly Version

Interactive Discussion 


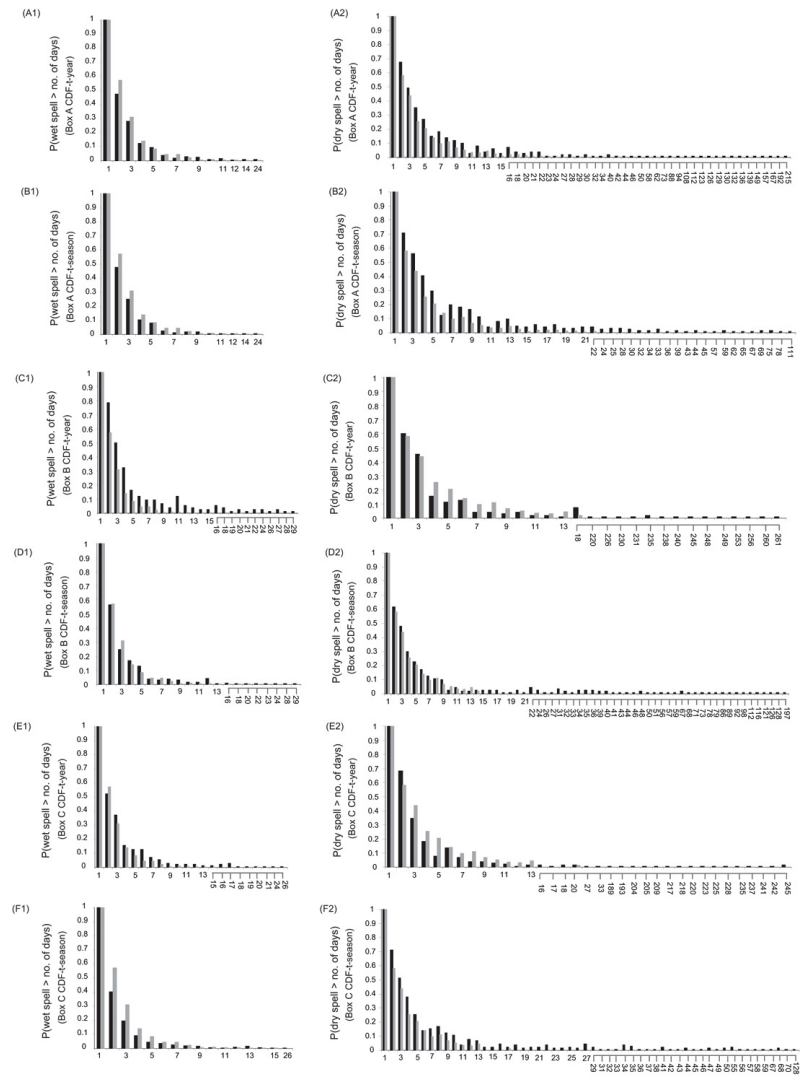

HESSD

7, 9523-9565, 2010

Coupling statistically downscaled GCM

outputs with a basin-lake model

M. Troin et al.

\section{Title Page}

\section{Abstract}

Conclusions

Tables

14

4

Back
Introduction

References

Figures

$\rightarrow$

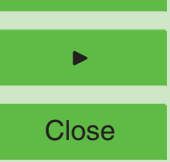

Full Screen / Esc

Printer-friendly Version

Interactive Discussion LMDZ box $B$ by CDF-t-season, (E) downscaled LMDZ box $C$ by CDF-t-year, and $(F)$ downscaled LMDZ box $C$ by CDF-t-season.

Fig. 4. Probabilities of duration of wet (first column) and dry (second column) spells for precipitation pattern-based simulated (black) and observed (grey) precipitation during the PDM 1973-1989 calibration period for (A) downscaled LMDZ box A by CDF-t-year, (B) downscaled LMDZ box A by CDF-t-season, (C) downscaled LMDZ box B by CDF-t-year, (D) downscaled 


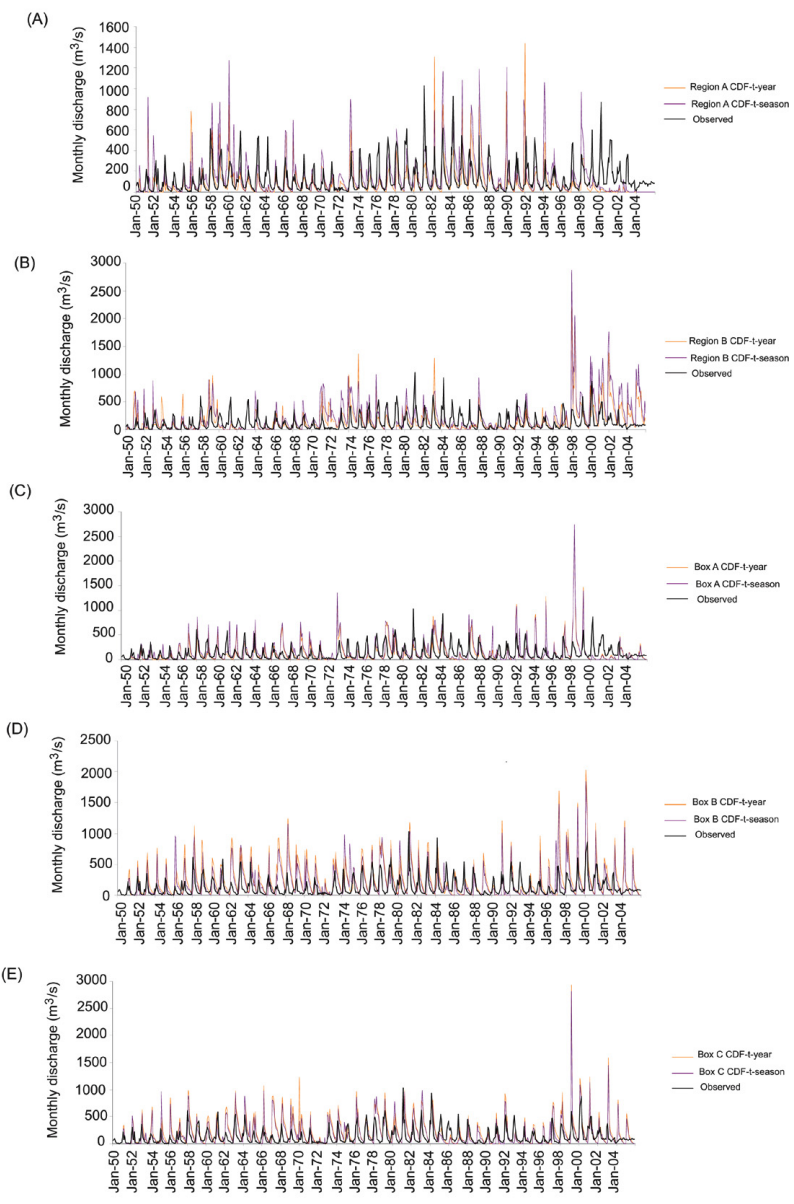

\section{HESSD}

7, 9523-9565, 2010

Coupling statistically downscaled GCM outputs with a basin-lake model

M. Troin et al.

\section{Title Page}

Abstract

\section{Conclusions}
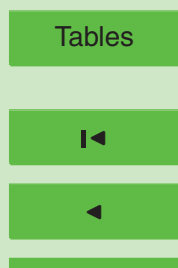

Back

\section{Introduction}

References

Figures

$>$ I

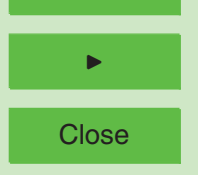

Full Screen / Esc

Printer-friendly Version

Interactive Discussion Fig. 5. Observed (black line) and simulated monthly discharge using CDF-t-year (orange NCEP/NCAR region B, (C) LMDZ box A, (D) LMDZ box B, and (E) LMDZ box C. 


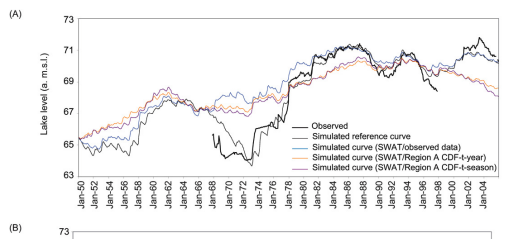

HESSD

7, 9523-9565, 2010

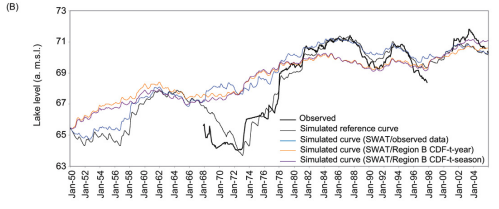

Coupling statistically downscaled GCM

outputs with a basin-lake model

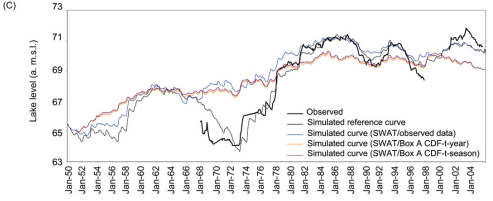

M. Troin et al.
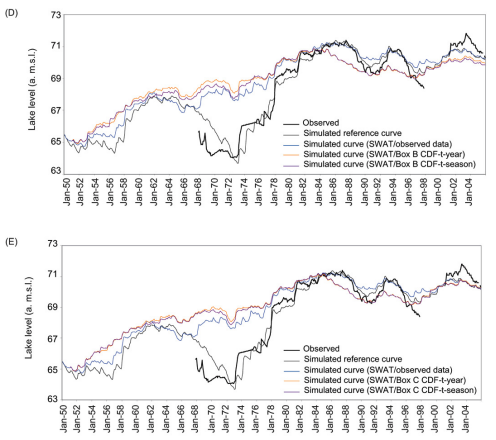

Fig. 6. Observed (bold line) and simulated lake levels of Laguna Mar Chiquita using observed (simulated reference curve; black line), simulated Rio Sali-Dulce discharge using observed meteorological data (SWAT/observed data; blue line), CDF-t-year (orange line) and CDF-tseason (purple line) over 1950-2005 for (A) NCEP/NCAR region A, (B) NCEP/NCAR region B, (C) LMDZ box A, (D) LMDZ box B, and (E) LMDZ box C.

Title Page

Abstract Introduction

Conclusions References

Tables Figures

14

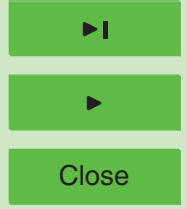

Back

Full Screen / Esc

Printer-friendly Version

Interactive Discussion 

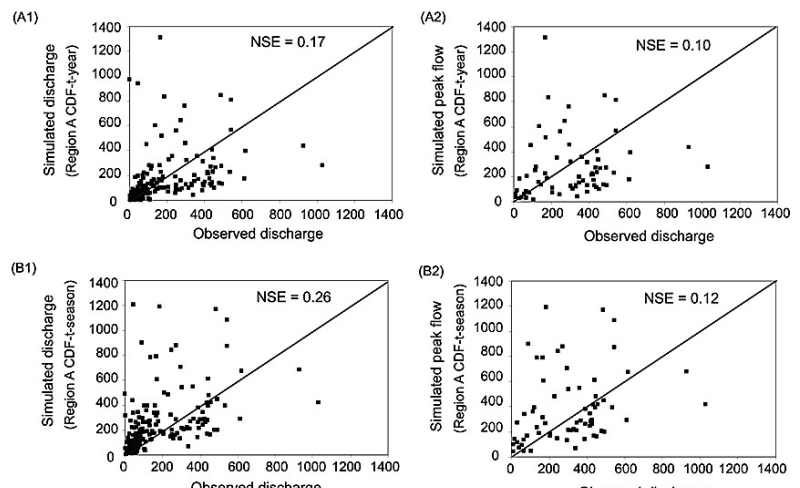

Observed discharge
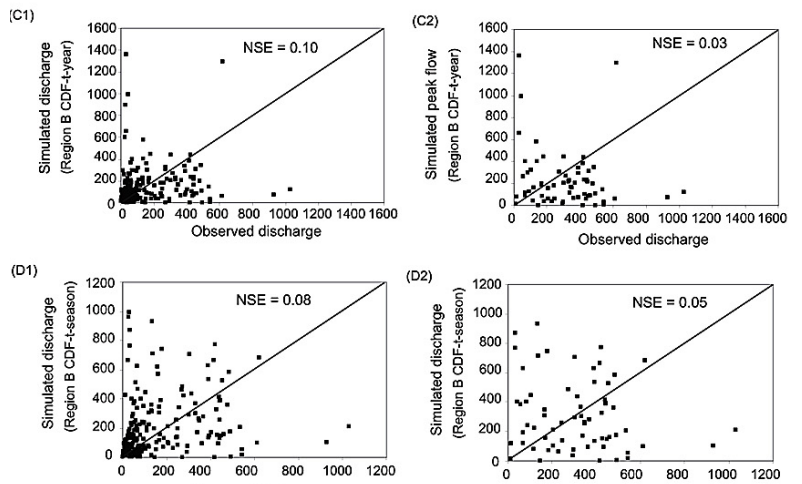

Observed discharge

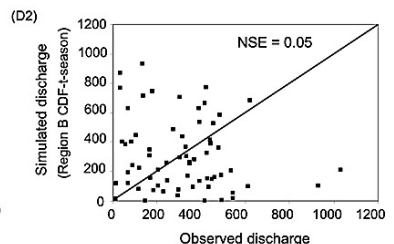

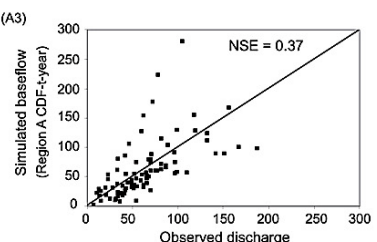
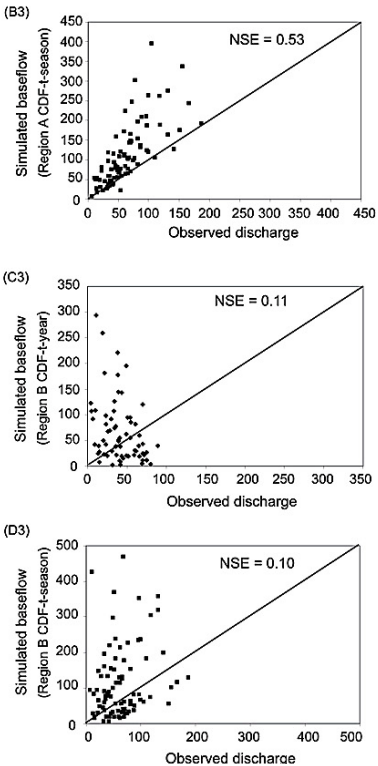

Fig. A1. Scatter plots of measured versus simulated monthly discharge $\left(\mathrm{m}^{3} \mathrm{~s}^{-1}\right)$ and the corresponding Nash-Sutcliffe coefficient of efficiency statistic (NSE) over 1973-1989 using (A) downscaled NCEP/NCAR region A by CDF-t-year, (B) downscaled NCEP/NCAR region A by CDF-t-season, (C) downscaled NCEP/NCAR region B by CDF-t-year, and (D) downscaled NCEP/NCAR region $B$ by CDF-t-season.

\section{HESSD}

7, 9523-9565, 2010

Coupling statistically downscaled GCM

outputs with a basin-lake model

M. Troin et al.

Title Page

Abstract

Introduction

Conclusions

References

Tables

Figures

14

$>$ I

4

Back

Close

\section{Full Screen / Esc}

Printer-friendly Version

Interactive Discussion 

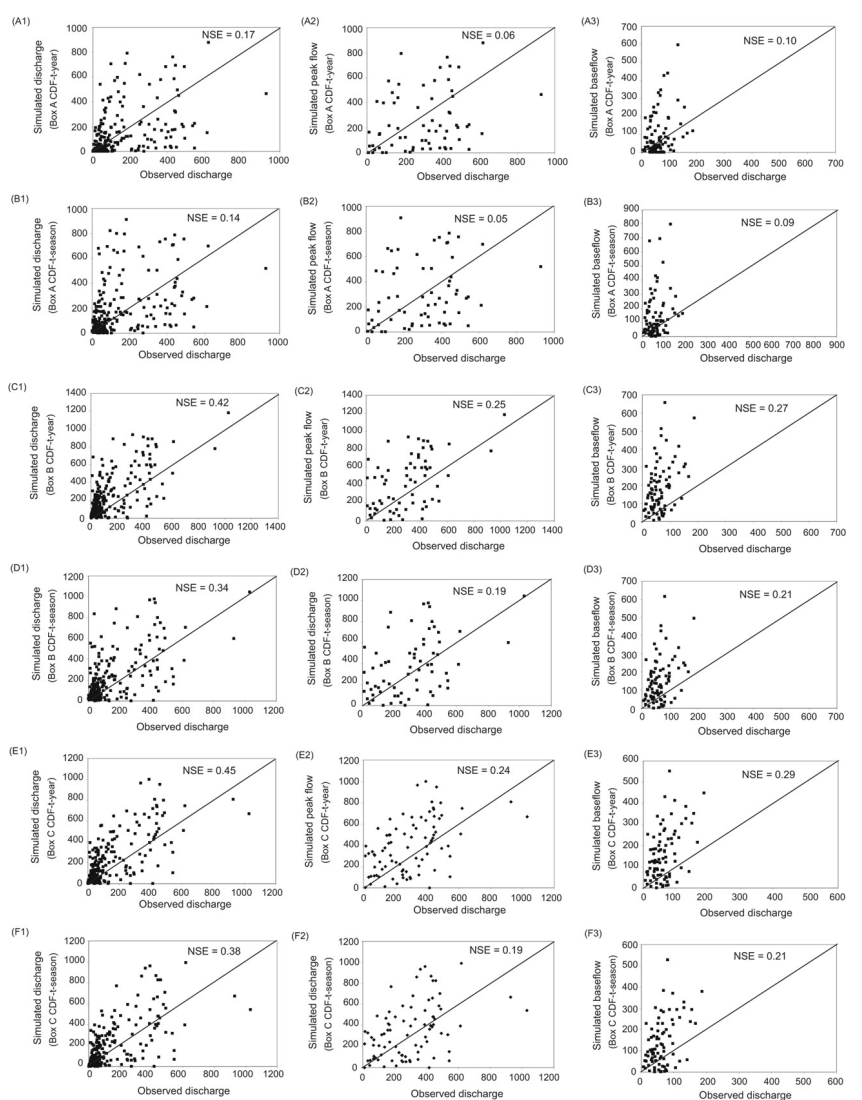

Fig. A2. Scatter plots of measured versus simulated monthly discharge $\left(\mathrm{m}^{3} \mathrm{~s}^{-1}\right)$ and the corresponding Nash-Sutcliffe coefficient of efficiency statistic (NSE) over 1973-1989 using (A) downscaled LMDZ box A by CDF-t-year, (B) downscaled LMDZ box A by CDF-t-season, (C) downscaled LMDZ box B by CDF-t-year, (D) downscaled LMDZ box B by CDF-t-season, (E) downscaled LMDZ box $C$ by CDF-t-year, and (F) downscaled LMDZ box $C$ by CDF-t-season.

9561
HESSD

7, 9523-9565, 2010

Coupling statistically downscaled GCM outputs with a basin-lake model

M. Troin et al.

Title Page

Abstract

Introduction

Conclusions

References

Tables

Figures

14

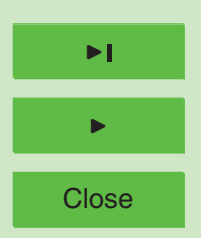

Back

Full Screen / Esc

Printer-friendly Version

Interactive Discussion 

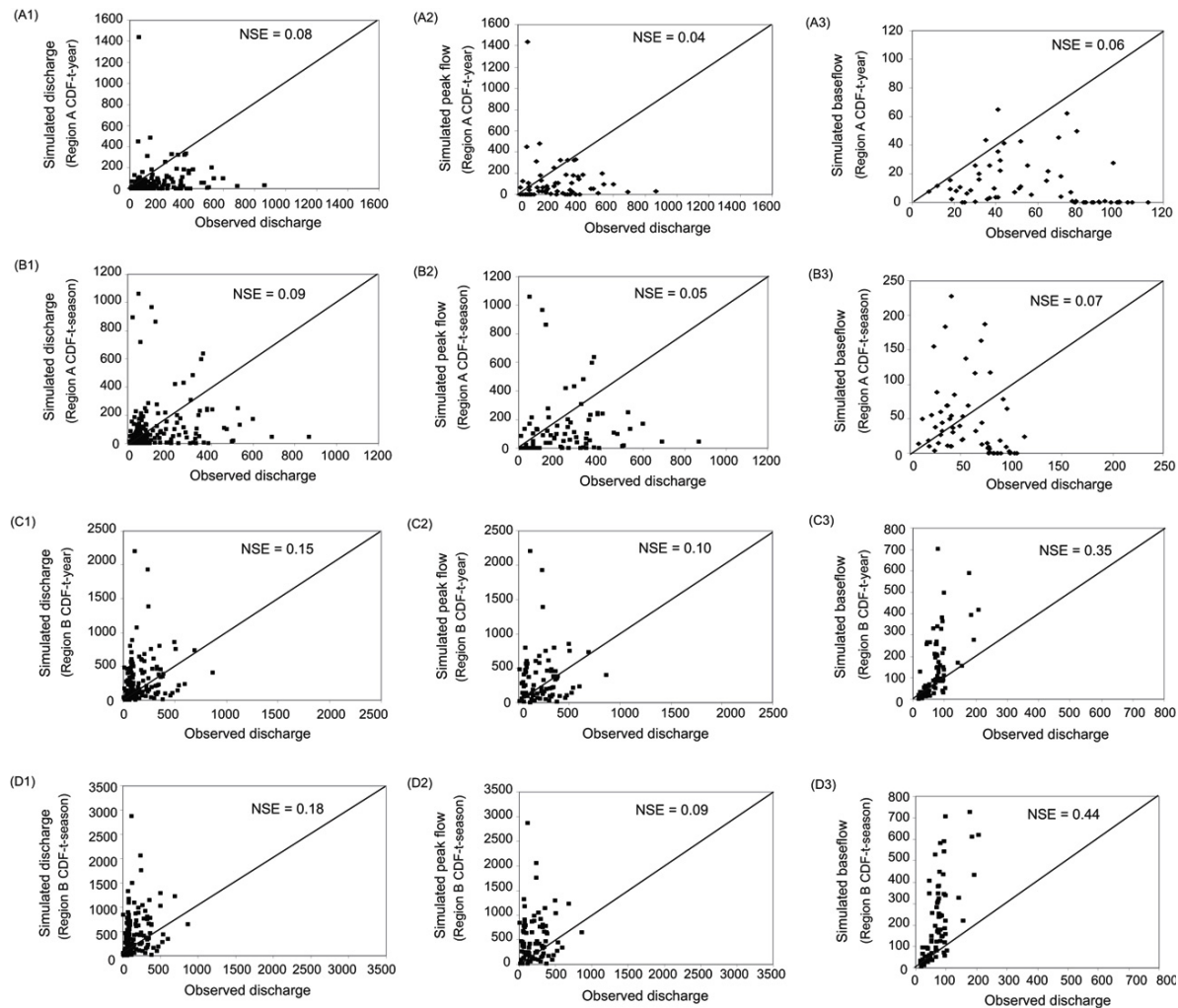

Fig. A3. Scatter plots of measured versus simulated monthly discharge $\left(\mathrm{m}^{3} \mathrm{~s}^{-1}\right)$ and the corresponding Nash-Sutcliffe coefficient of efficiency statistic (NSE) over 1990-2005 using (A) downscaled NCEP/NCAR region A by CDF-t-year, $(B)$ downscaled NCEP/NCAR region A by CDF-t-season, (C) downscaled NCEP/NCAR region B by CDF-t-year, and (D) downscaled NCEP/NCAR region $B$ by CDF-t-season.

\section{HESSD}

7, 9523-9565, 2010

Coupling statistically downscaled GCM

outputs with a basin-lake model

M. Troin et al.

Title Page

Abstract

Introduction

Conclusions

References

Tables

Figures

14

$\rightarrow$

4

Back

Close

\section{Full Screen / Esc}

Printer-friendly Version

Interactive Discussion 

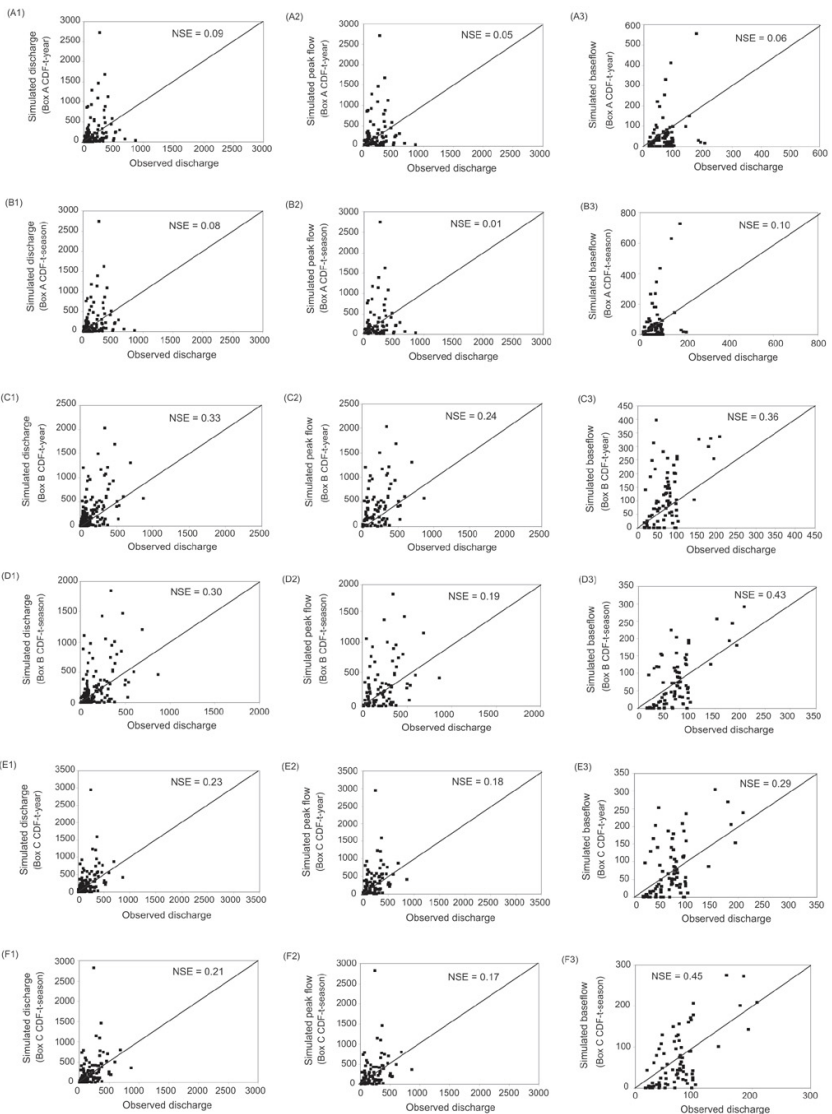

Fig. A4. Scatter plots of measured versus simulated monthly discharge $\left(\mathrm{m}^{3} \mathrm{~s}^{-1}\right)$ and the corresponding Nash-Sutcliffe coefficient of efficiency statistic (NSE) over 1990-2005 using (A) downscaled LMDZ box A by CDF-t-year, (B) downscaled LMDZ box A by CDF-t-season, (C) downscaled LMDZ box B by CDF-t-year, (D) downscaled LMDZ box B by CDF-t-season, (E) downscaled LMDZ box $C$ by CDF-t-year, and $(F)$ downscaled LMDZ box $C$ by CDF-t-season.
HESSD

7, 9523-9565, 2010

Coupling statistically downscaled GCM

outputs with a basin-lake model

M. Troin et al.

Title Page

Abstract

Introduction

Conclusions

References

Tables

Figures

14

$\rightarrow$

4

Back

Close

Full Screen / Esc

Printer-friendly Version

Interactive Discussion 

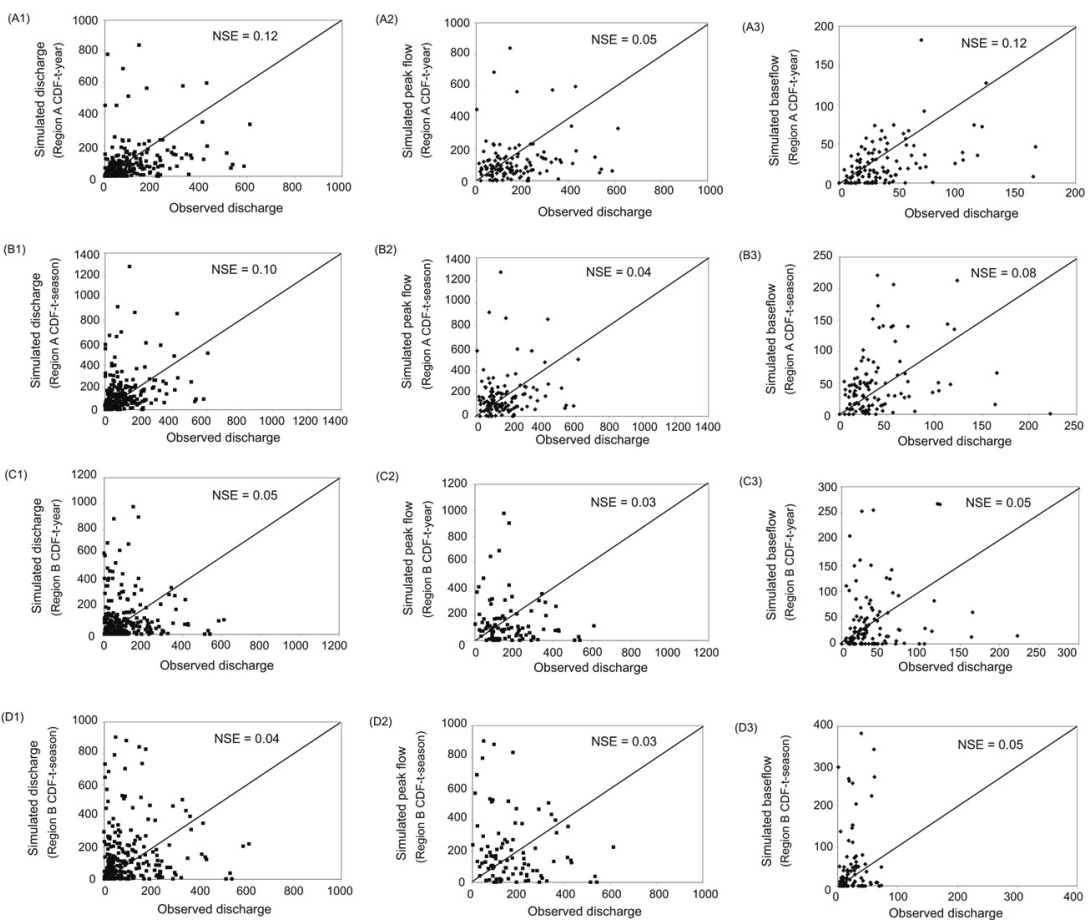

Fig. A5. Scatter plots of measured versus simulated monthly discharge $\left(\mathrm{m}^{3} \mathrm{~s}^{-1}\right)$ and the corresponding Nash-Sutcliffe coefficient of efficiency statistic (NSE) over 1950-1972 using (A) downscaled NCEP/NCAR region A by CDF-t-year, (B) downscaled NCEP/NCAR region A by CDF-t-season, (C) downscaled NCEP/NCAR region B by CDF-t-year, and (D) downscaled NCEP/NCAR region $B$ by CDF-t-season.
HESSD

7, 9523-9565, 2010

Coupling statistically downscaled GCM

outputs with a basin-lake model

M. Troin et al.

\section{Title Page}

\section{Abstract}

Introduction

Conclusions

References

Tables

Figures

14

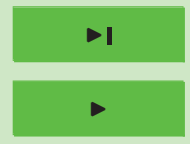

Back

Close

\section{Full Screen / Esc}

Printer-friendly Version

Interactive Discussion 

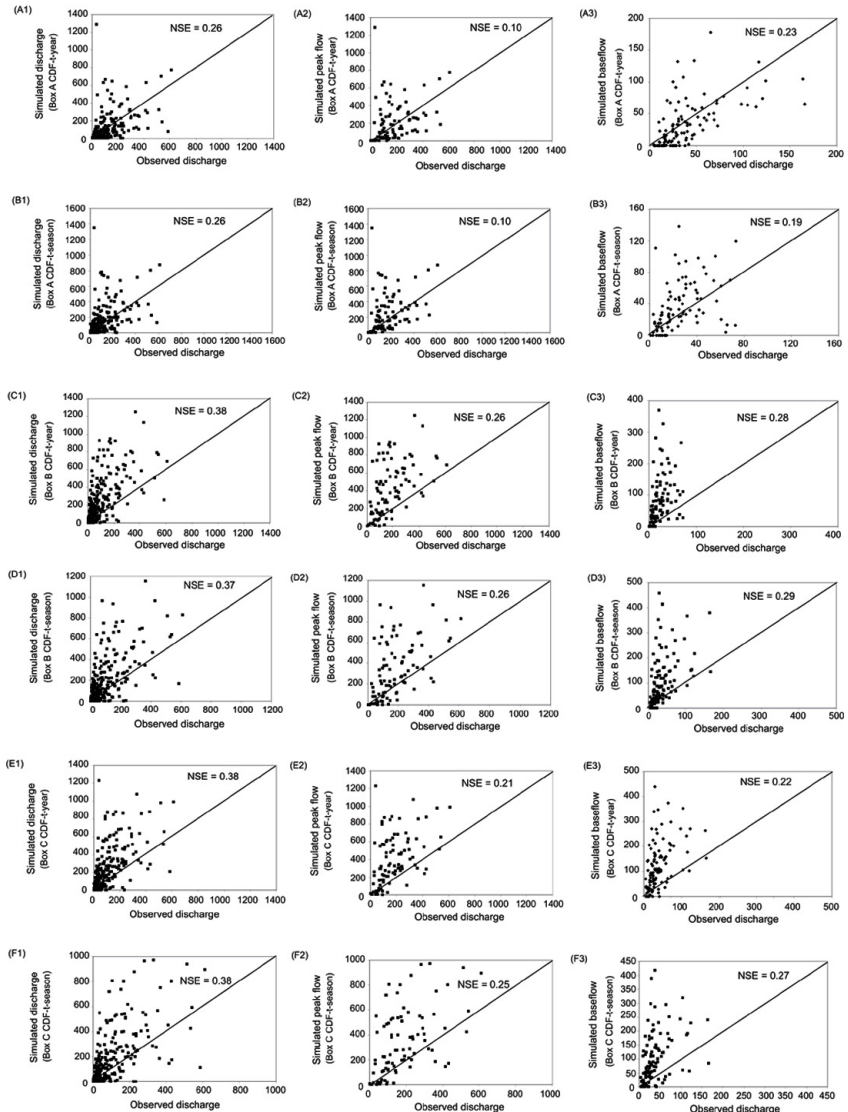

Fig. A6. Scatter plots of measured versus simulated monthly discharge $\left(\mathrm{m}^{3} \mathrm{~s}^{-1}\right)$ and the corresponding Nash-Sutcliffe coefficient of efficiency statistic (NSE) over 1951-1972 using (A) downscaled LMDZ box A by CDF-t-year, (B) downscaled LMDZ box A by CDF-t-season, (C) downscaled LMDZ box B by CDF-t-year, (D) downscaled LMDZ box B by CDF-t-season, (E) downscaled LMDZ box $C$ by CDF-t-year, and (F) downscaled LMDZ box $C$ by CDF-t-season.
HESSD

7, 9523-9565, 2010

Coupling statistically downscaled GCM

outputs with a basin-lake model

M. Troin et al.

Title Page

Abstract

Introduction

Conclusions

References

Tables

Figures

14

$\rightarrow$

4

Back

Close

Full Screen / Esc

Printer-friendly Version

Interactive Discussion 